\title{
Hippomaneae (Euphorbiaceae) no Parque Nacional da Chapada dos Veadeiros, Goiás, Brasil
} Hippomaneae (Euphorbiaceae) in the Chapada dos Veadeiros National Park, Goiás, Brazil

\author{
Pablo Henrique Bueno dos Santos ${ }^{1}$, Rodolfo Carneiro Sodré $e^{1,2} \&$ Marcos José da Silva ${ }^{1}$
}

\begin{abstract}
Resumo
As Euphorbiaceae da tribo Hippomaneae são complexas e pouco estudadas taxonomicamente em decorrência de possuírem flores diminutas e homogêneas. Com base em coletas mensais desde 2011, análise de coleções de herbários e de literatura específica, foi realizado o tratamento taxonômico de Hippomaneae no Parque Nacional Chapada dos Veadeiros, área cuja flora é rica e pouco conhecida. Foram encontradas 15 espécies pertencentes a cinco gêneros: Microstachys e Sapium, os mais diversos, com nove e três espécies respectivamente, seguidos por Gymnanthes, Maprounea e Sebastiania com uma espécie cada. Sapium haematospermum é uma nova ocorrência no estado de Goiás. São apresentadas uma chave de identificação para as espécies, descrições e comentários taxonômicos, além da transferência de Sebastiania anisodonta e S. salicifolia para o gênero Microstachys, e uma lectotipificação.
\end{abstract}

Palavras-chave: diversidade, flora do Cerrado, nomenclatura, riqueza.

\begin{abstract}
The Euphorbiaceae of the tribe Hippomaneae are complex and poorly studied taxonomically due to having small and homogeneous flowers. Based on monthly collections since 2011, analysis of herbarium collections and specific literature was performed the taxonomic treatment to the Hippomaneae present in the Chapada dos Veadeiros National Park, an area whose flora is rich and little known. Fifteen species belonging to five genera were found: Microstachys and Sapium, the most diverse, with nine and three species respectively, followed by Gymnanthes, Maprounea and Sebastiania with one species each. Sapium haematospermum is firstly recorded in the state of Goiás. Species identification key, species descriptions with comments and illustrations, besides the transference of Sebastiania anisodonta and S. salicifolia to the genus Microstachys and a lectotipification.
\end{abstract}

Key words: diversity, flora of Cerrado, nomenclature, richness.

\section{Introdução}

Euphorbiaceae sensu stricto reúne 246 gêneros e 6.300 espécies, predominantemente tropicais (Wurdack \& Davis 2009). Pode ser reconhecida principalmente pelas folhas alternas, presença de látex, flores unissexuais, mono ou diclamídeas, as pistiladas com gineceu 3-carpelar, 3-locular e 1-ovulado, frutos capsulares e sementes usualmente carunculadas (Webster 1994; Wurdack \& Davis 2009). No Brasil, compreende 64 gêneros e 948 espécies (BFG 2015), sendo uma das famílias mais complexas taxonomicamente e representativas da flora, porém ainda pouco estudada, sobretudo em áreas savânicas da porção central do país (Secco et al. 2012).

A subdivisão de Euphorbiaceae em subfamílias é controversa, porém de acordo com Wurdack et al. (2005) e Wurdack \& Davis (2009) esta família compreende as subfamílias Cheilosoideae (Müller Arg.) K. Wurdack \& Petra Hoffman, Acalyphoideae Beilschmied, Crotonoideae Beilschmied e Euphorbioideae, sendo esta última monofilética e reconhecida pela presença do látex branco e leitoso com laticíferos não articulados e flores sem disco ou pétalas (Webster 1994; Wurdack et al. 2005).

\footnotetext{
${ }^{1}$ Universidade Federal de Goiás, Inst. Ciências Biológicas, Depto. Botânica, C.P. 131, 74001-970, Goiânia, GO, Brasil.

${ }^{2}$ Autor para correspondência: sodrerodolfo@gmail.com
} 
Euphorbioideae concentra as tribos Euphorbieae Dumort, a maior da família, com cerca de mais de 2.000 espécies caracterizadas pelo pseudanto do tipo ciátio, e Hippomaneae com 33 gêneros e aproximadamente 300 espécies (Esser et al. 1997; Esser 2012) com gemas envoltas por brácteas, flores usualmente monoclamídeas, sem disco e com cálice diminuto, inflorescências tirsoides com címulas estaminadas apicais e flores pistiladas basais protegidas por uma bráctea geralmente biglandular (Esser 2012; Oliveira 2014).

No Brasil, o conhecimento sobre Hippomaneae após a Flora brasiliensis (Müller 1873), avançou com os estudos para as floras de Pernambuco (Santos \& Sales 2009) e São Paulo (Pscheidt \& Cordeiro 2012); com a revisão de Sebastiania Spreng (Melo 2005), Actinostemon Mart. ex Klotzsch (Eymael 2012), Gymnanthes Sw. (Oliveira 2014), Microstachys A. Juss. (Pscheidt 2015). Mais recentemente, Esser (2012) realizou uma sinopse para o país e lhe atribuiu 13 gêneros e cerca de 120 espécies. Mesmo assim, estudos taxonômicos sobre esta tribo ainda são escassos, principalmente na região Centro-Oeste do país, para onde nenhum estudo sobre a tribo foi realizado. Apresentamos o tratamento taxonômico das Hippomaneae ocorrentes no Parque Nacional da Chapada dos Veadeiros.

\section{Material e Métodos}

O Parque Nacional da Chapada dos Veadeiros (PNCV) está localizado nos municípios de Alto Paraíso de Goiás, Cavalcante e Colinas do Sul, entre as coordenadas $13^{\circ} 50^{\prime}-14^{\circ} 12^{\prime} \mathrm{S}$ e $47^{\circ} 24^{\prime}-$ $47^{\circ} 58^{\prime} \mathrm{W}$, e altitude de 800 a $1.650 \mathrm{~m}$, totalizando uma superfície de 65.514 ha. Possui distintas fitofisionomias (Fig. 1), embora as predominantes sejam o Cerrado sensu stricto, o cerrado rupestre e os campos limpos, sujos e rupestres. Seu clima é o $\mathrm{CWbl}$ com precipitação média anual entre 1.500 e $1.750 \mathrm{~mm}$ e temperatura por volta de 24 a $26{ }^{\circ} \mathrm{C}$. Seu relevo compreende chapadas compostas de rochas pertencentes ao grupo Araí, serras depressões e "canyons" (Brasil 1982; Felfili 2007; Veiga 2000).

Foram realizadas excursões mensais desde 2011 ao PNCV para coleta de material botânico, conforme Mori et al. (1989). O material coletado encontra-se depositado no Herbário da Universidade Federal de Goiás. A espécies foram identificadas através de literatura especializada (e.g., Müller 1874; Webster 1994; Santos \& Sales 2009; Silva et al. 2016), comparações com coleções dos herbários
ALCB, CEN, CEPEC, E, HUEFS, IBGE, K, M, MG, MO, NY, SP, SPF, UB, UFG e W (acrônimos de acordo com Thiers, continuamente atualizado), incluindo typus, e descritas com base em suas variações morfológicas. Na descrição das espécies foram adotadas as terminologias da literatura consultada para identificá-las, a qual também embasou os comentários sobre distribuição. As ilustrações foram feitas em um estereomicroscópio Zeiss com câmara clara acoplada e constam de caracteres relevantes para o reconhecimento das espécies. A terminologia adotada na designação dos tipos vegetacionais apresentados no artigo seguem Ribeiro \& Walter (1998).

\section{Resultados e Discussão}

Neste estudo Hippomaneae mostrou-se representada por 15 espécies pertencentes aos gêneros Gymnanthes Sw., Maprounea Aubl., Microstachys A. Juss., Sapium P. Browne e Sebastiania Spreng.

Gymnanthes compreende 16 espécies, sendo 12 neotropicais, duas africanas e uma asiática (Oliveira 2014). G. schottiana foi a única espécie do gênero registrada no PNCV.

Maprounea é Paleotropical e possui quatro espécies, três delas (M. guianensis, M. brasiliensis A. St.-Hil e $M$. amazonica Esser) presentes no Brasil (Esser 1999), uma das quais, M. guianensis, registrada na área estudada.

Microstachys é Pantropical e reúne 24 espécies, 19 delas presentes nas Américas (Psheidt 2015), 15 das quais presentes no Brasil (BFG 2015; Esser 1997; Silva \& Esser 2011) e nove neste estudo.

Sapium engloba 21 espécies neotropicais (Kruijt 1996), 10 das quais presentes no Brasil, e três S. glandulosum (L.) Morong, S. haematospermum Müll. Arg. e S. obovatum Klotzsch ex Müll. Arg., aqui encontradas, sendo a segunda primeiramente referida para o estado de Goiás.

Sebastiania inclui 17 espécies americanas (Melo 2006), 12 encontradas na América do Sul, oito nas regiões Nordeste e Sudeste do Brasil e uma, S. brasiliensis Spreng, no PNCV.

As espécies encontradas neste estudo ocorrem em distintos tipos fitofisionômicos, no entanto, algumas delas como G. schotiana, $M$. brasiliensis e $S$. brasiliensis possuem predileções por matas ciliares ou de galerias, enquanto, aquelas pertencentes aos gêneros Microstachys e Sapium habitam usualmente no cerrado sensu stricto ou rupestre, embora possam também alcançar os 

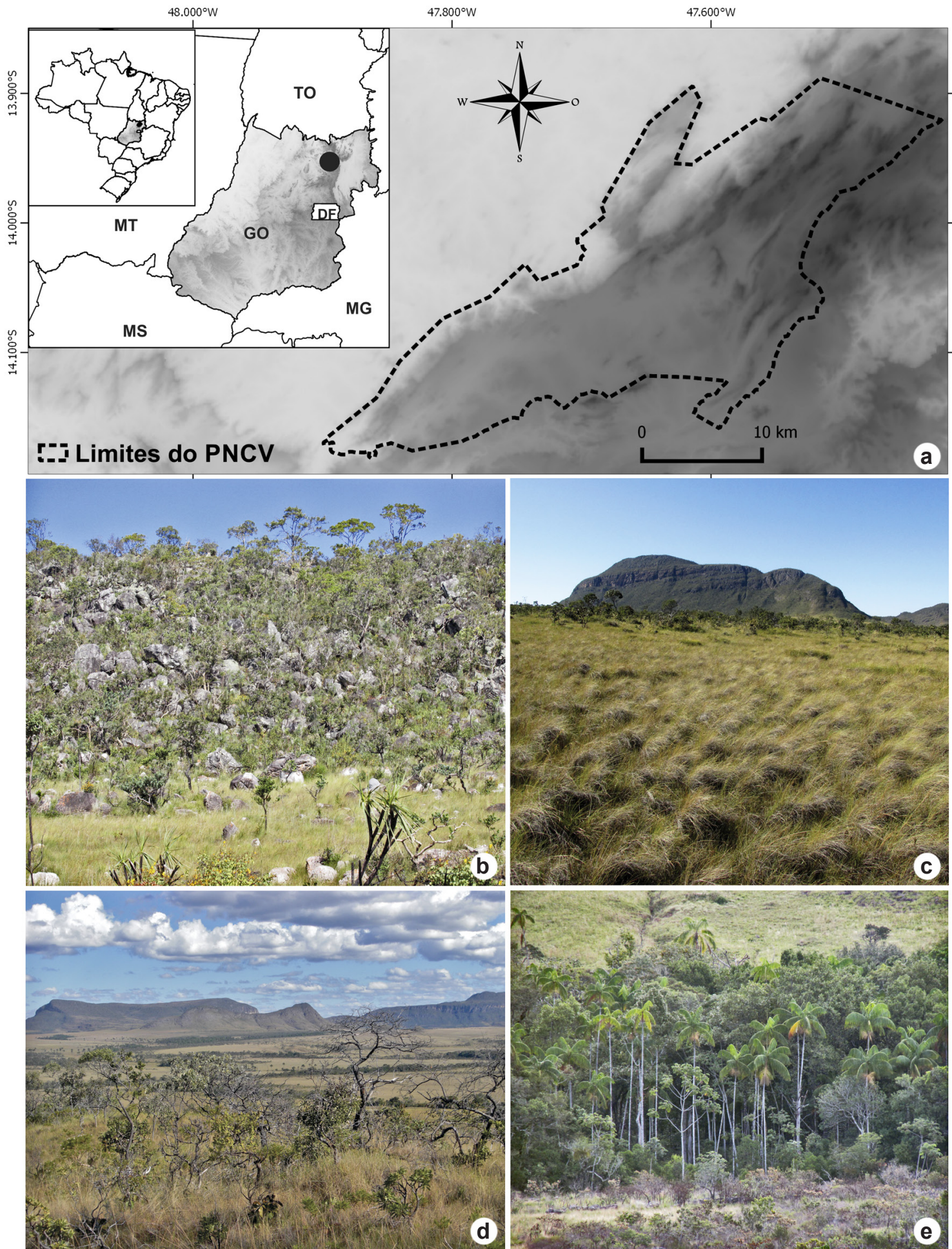

Figura 1 - a. Localização do Parque Nacional da Chapada dos Veadeiros; b. Cerrado rupestre; c. Campo limpo; d. Cerrado sensu stricto; e. Floresta de galeria.

Figure 1 - a. Location of the Chapada dos Veadeiros National Park; b. Cerrado rupestre; c. Campo limpo; d. Cerrado sensu stricto; e. Gallery forest. 
campos limpos e úmidos como é o caso de $M$. bidentata e $M$. crassifolia.

Se compararmos nossos resultados com os obtidos para a tribo por Santos \& Sales (2000) para Pernambuco e Pscheidt \& Cordeiro (2012) para São Paulo verificamos certa expressividade, haja vista nestes estudos a tribo ter se representado por 12 e 22 espécies, respectivamente e também se considerarmos que a área do PNCV, que é de $655,14 \mathrm{~km}^{2}$, é bastante inferior às áreas dos estados de Pernambuco e São Paulo, 98.312 km² e 248.209 $\mathrm{km}^{2}$, respectivamente. Destacamos ainda que os gêneros de Hippomaneae presentes no PNCV e nos estudos previamente citados são praticamente os mesmos com exceção Actinostemon Sw., cujas espécies ocorrem usualmente em florestas litorâneas, estacionais ou não, ou interioranas, mas não relacionadas ao cerrado sensu stricto; de Mabea Aubl. e Senefeldera Mart. cuja ocorrência está mais associada a áreas de mata atlântica ou da floresta amazônica, e de Stillingia Garden ex L. que no Brasil é típico de ambientes abertos de florestas sazonalmente secas como as caatingas nordestinas. Estes últimos quatro gêneros foram encontrados tanto em Pernambuco quanto em São Paulo.

Microstachys mostrou-se representado em São Paulo e em Pernambuco por cinco e duas espécies, respectivamente, enquanto que no PNCV nove de suas espécies foram registradas, o que corresponde a $47 \%$ e $60 \%$ do total de espécies referidas para as Américas (Pscheidt 2015) e Brasil (BFG 2015), respectivamente, evidenciando a predileção dos mesmo por áreas savânicas da porção central do país.

A chave abaixo serve para o reconhecimento das espécies de Hippomaneae ocorrentes no PNCV e consta dos caracteres mais conservados e diagnósticos delas.

\section{Chave de identificação das espécies de Hippomaneae ocorrentes no Parque Nacional da Chapada dos Veadeiros}

1. Ramos com terminações espinescentes; tirsos com címulas estaminadas 1-floras

1'. Ramos não espinescentes; tirsos com címulas estaminadas 2 ou 3 -floras.

2. Folhas com um par de glândulas acropeciolares; flores estaminadas com dois estames; sementes com arilo vermelho.

3. Plantas subarbustivas; lâmina foliar linear a oblanceolada; glândulas acropeciolares globosas, usualmente na face superior do pecíolo 12. Sapium haematospermum

3'. Plantas arbustivas ou arbóreas; lâmina foliar largamente oblonga, oblongo-elíptica ou oboval; glândulas acropeciolares cilíndricas ou cônicas, laterais ao pecíolo.

4. Lâmina foliar com margem revoluta, ápice inflexo-cuculado; cálice estaminado com lobos irregularmente serreados 13. Sapium glandulosum

4'. Lâmina foliar com margem plana, ápice obtuso; cálice estaminado com lobos inteiros 14. Sapium obovatum

2'. Folhas sem glândulas acropeciolares; flores estaminadas com 3 estames; sementes sem arilo.

5. Subarbustos com látex claro escasso; tirsos opostos às folhas; frutos corniculados; sementes cilíndricas.

6. Folhas sésseis a subsésseis com margem revoluta, base conspicuamente cordada

8. Microstachys ditassoides

6'. Folhas pecioladas com margem plana, base obtusa ou mais raramente ligeiramente cordada.

7. Plantas com até $15 \mathrm{~cm}$ alt.; caule e ramos vermelhos a róseos com entrenós bem evidentes; folhas crassas.

6. Microstachys crassifolia

7'. Plantas maiores que $20 \mathrm{~cm}$ alt.; caule e ramos castanhos com entrenós inconspícuos; folhas cartáceas ou membranáceas.

8. Plantas decumbentes, muito delicadas; inflorescências $0,3-2 \mathrm{~cm}$ compr., delgadas.

9. Folhas seríceas na face adaxial, margem com serras adpressas no terço inferior, curvas no superior 3. Microstachys anisodonta

9'. Folhas glabras ou híspidas na face adaxial, margem com serras curvas em toda a extensão 5. Microstachys corniculata 
8'. Plantas eretas, virgadas; tirsos 3-5 cm compr., robustos.

10. Folhas lineares ou lanceoladas.

11. Folhas com margem serreada, com glândulas uniformemente distribuídas; flores pistiladas com estiletes subulados 10. Microstachys salicifolia

11'. Folhas com margem inteira ou raramente esparsamente serreada com glândulas irregularmente distribuídas; flores pistiladas com estiletes subglobosos.

4. Microstachys bidentata

10'. Folhas oblongas, oblongo-elípticas ou oval-elípticas.

12. Folhas indumentadas em ambas as faces; flores pistiladas indumentadas, incluindo os estiletes; ovário e frutos com córneos basais ou apicais, os frutos com todos os mericarpos férteis.

13. Margem foliar com serras adpressas; tirsos 2,5-4,6 cm; cápsulas pubescentes...... ... 9. Microstachys hispida

13'. Margem foliar com serras curvas; tirsos com 1-4 cm; cápsulas densa e curtamente velutinas 7. Microstachys daphnoides

12'. Folhas glabras, raro pubescentes ao longo da nervura principal, na face abaxial; flores pistiladas glabras; ovário e frutos densa e irregularmente corniculados, os frutos com um dos mericarpos reduzido ou abortado

11. Microstachys serrulata

5'. Arvoretas ou árvores com látex branco abundante; tirsos terminais ou axilares; frutos sem córneos; sementes elipsoides ou ovoides.

14. Folhas com glândulas arredondadas basais na face abaxial e impressas; tirsos axilares, globosos com flores pistiladas basais e opostas; sementes com carúncula avermelhada a amarelada

2. Maprounea guianensis

14'. Folhas sem glândulas arredondadas basais; tirsos terminais, cilíndricos com flores pistiladas alternas; sementes sem carúnculas. 15. Sebastiania brasiliensis

1. Gymnanthes schottiana Müll. Arg., Linnaea 32: 96. 1863. Fig. 2a-f

Arbusto 1,60-2,80 m alt.; látex claro, escasso; ramos lenhosos enegrecidos a vináceos nas partes jovens e com terminações espinescentes, glabros; lâmina 2,2-3,9 × 0,3-0,9 mm, elíptica, oblongo-elíptica, às vezes espatulada, base obtusa, ápice obtuso a arredondado, margem inteira com glândulas oblongas; face adaxial verde escuro, face abaxial verde-clara. Pecíolo $0,5-1 \mathrm{~mm}$ compr. Tirsos 1,4-2,6 cm compr., bissexuais com 1-3 flores pistiladas basais e mais que 20 címulas estaminadas 1-floras dispostas espiraladamente; brácteas pistiladas $0,8-1 \times 1,2-1,4 \mathrm{~mm}$, ovais, ápice obtuso, margem denticulada; brácteas estaminadas $0,7-1 \times 0,6-0,7 \mathrm{~mm}$, lanceoladas, ápice agudo; flores estaminadas $0,7-1,3 \mathrm{~mm}$, pedicelo $0,4-1,1$ $\mathrm{mm}$ compr., sépalas $0,5-0,7 \times 0,2-0,3 \mathrm{~mm}$, espatuladas, ápice agudo, margem inteira, 3 estames unidos na base; flores pistiladas 2,3-4,6 mm compr., pedicelo 1,2-3 mm compr., sépalas $0,8-1 \times 1-1,1 \mathrm{~mm}$, oval, ápice agudo, margem lacerada, com glândulas digitadas na base, ovário $0,4-0,6 \times 0,5-0,7 \mathrm{~mm}$, glabro, globoso, 2 diminutos córneos por carpelo na porção superior; estiletes fortemente curvos. Cápsula 0,3-0,4 × 0,5-0,7 cm, globosa, rosada com diminutos córneos; pedicelo 0,6-2,5 cm compr., filiforme; sementes 2,8-3,2 $\times$ 2-2,1 mm, oblongas, amarronzada, fosca, ápice levemente achatado, sem carúncula.

Material examinado: Alto Paraíso de Goiás, margem do Rio Preto, região das Corredeiras, 14'9'27,2"S, 47050'10,1'W, 920 m, 8.III.2013, M.J. Silva et al. 4780, 4781, 4787 (UFG). Cavalcante, imediações das corredeiras, $3 \mathrm{~m}$ a partir do Rio Preto, 14.9'17,4'S, 47050'8,5”'W, 816 m, 8.III.2013, M.J. Silva et al. 4787, 4788 (UFG); leito do Rio Preto, entre as rochas das Corredeiras, 8.III.2013, R.C. Sodré et al. 595, 596 (UFG).

Gymnanthes schottiana ocorre na Argentina, Brasil, Paraguai e Uruguai, sendo no Brasil registrada para as regiões Sul (toda a região), Sudeste (Minas Gerais, Rio de Janeiro e São Paulo) e Centro-Oeste (Distrito Federal, Goiás, Mato Grosso do Sul), segundo Oliveira (2014) e BFG (2015). No PNCV, forma expressivas populações às margens do Rio Preto e pode ser reconhecida pelos ramos enegrecidos com terminações espinecentes, címulas estaminadas 1-floras, pedicelo frutificado filiforme, grande (até 2,5 cm compr.), além de cápsulas globosas, rosadas e com diminutos córneos. 


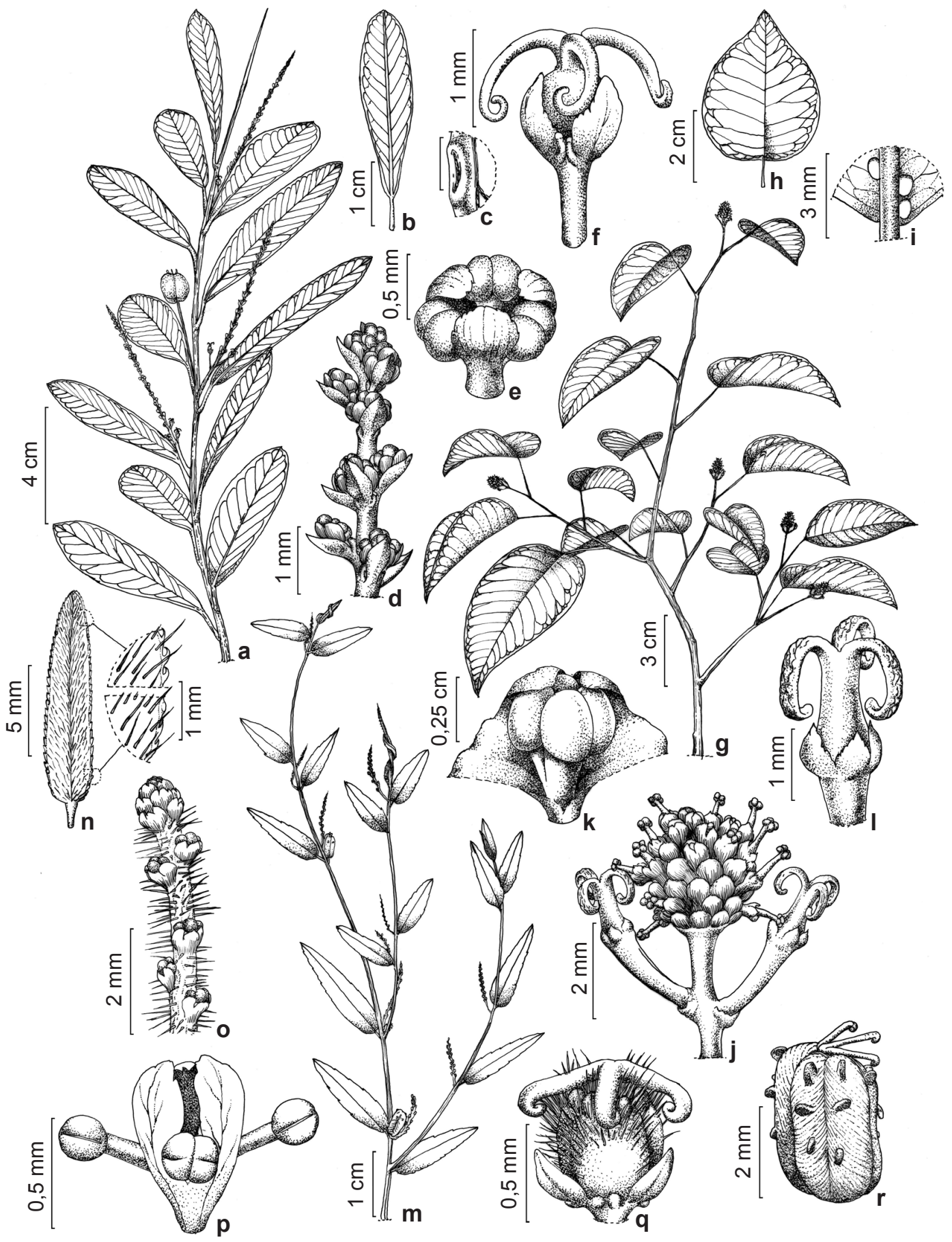

Figura 2 - a-f. Gymnanthes schottiana - a. ramo florido; b. folha; c. detalhe da glândula na margem da folha; d. detalhe da inflorescência mostrando as címulas estaminadas; e. flor estaminada; f. flor pistilada. g-1. Maprounea guianensis - g. ramo florido; h. folha; i. detalhe das glândulas arredondas basais; j. tirsos globosos; k. flor estaminada; 1 . flor pistilada. m-r. Microstachys anisodonta $-\mathrm{m}$. ramo florido; $\mathrm{n}$ folha, com detalhe da margem com dentes adpressos na porção proximal e curvos na distal; o. detalhe da inflorescência mostrando as címulas estaminadas; $p$. flor estaminada; q. flor pistilada; r. cápsula. Figure 2 - a-f. Gymnanthes schottiana - a. flowering branch; b. leaf; c. detail of the gland on leaf margin; d. detail of the inflorescence showing staminate cymules; e. staminate flower; f. pistillate flower. $\mathrm{g}-1$. Maprounea guianensis - g. flowering branch; $h$. leaf; i. detail of the rounded basilaminar glands; $j$. globose thyrses; $\mathrm{k}$. staminate flower; 1 . pistillate flower. m-r. Microstachys anisodonta $-\mathrm{m}$. flowering branch; $\mathrm{n}$. leaf, with detail of the proximal portion of the margin with adpress teeth and distal portion with curved teeth; $\mathrm{o}$. detail of the inflorescence showing staminate cymules; $p$. staminate flower; q. pistillate flower; $r$. capsule. 
2. Maprounea guianensis Aubl., Hist. Pl. Guiane 2: 895.1775.

Figs. 2g-1; 7a-c

Árvore ou menos frequentemente arbusto 0,7 $7 \mathrm{~m}$ alt.; látex branco, abundante; ramos esverdeados a cinéreos, glabros. Folhas alternas, membranáceas, pecioladas; lâmina 2,6-6,7 × 1,3-4,4 cm, oval a oval-elíptica, base obtusa a arredondada, ápice agudo, às vezes curtamente acuminado; face adaxial verde escura, face abaxial verde-clara ou opaca com glândulas aredondadas basais e impressas. Tirsos $0,2-0,6 \mathrm{~cm}$ compr., terminais, globosos, bissexuais, pedúnculo $0,2-2,2 \mathrm{~mm}$ compr., flores pistiladas basais, usualmente aos pares, opostas ou subopostas, e estaminadas em címulas 2-floras; brácteas pistiladas 1-2,3 × 1-1,3 mm, ovais, ápice agudo; brácteas estaminadas $0,7-1 \times 0,4-0,6 \mathrm{~mm}$, ovais, ápice agudo; flores estaminadas $1-2,2 \mathrm{~mm}$ compr., sésseis, sépalas $0,7-1 \times 0,3-0,5 \mathrm{~mm}$, espatuladas, ápice arredondado, margem discretamente lacerada; flores pistiladas $2-4 \mathrm{~mm}$ compr., pedicelo $0,5-2 \mathrm{~mm}$ compr., sépalas $0,6-1,2 \times 0,7-1 \mathrm{~mm}$, ovais, ápice agudo, margem ligeiramente serreada, ovário 0,9 $1,2 \times 0,8-1,1 \mathrm{~mm}$, globoso, sem córneos. Cápsula $0,6-0,7 \times 0,7-0,9 \mathrm{~cm}$, globosa, lustrosa, glabra; sementes $0,2-0,7 \times 0,2-0,5 \mathrm{~cm}$, ovais, faveoladas, carúncula avermelhada a alaranjada.

Material examinado: Alto Paraíso de Goiás, próximo à entrada de acesso à sede do Parque, $14^{\circ} 10^{\prime} 10,5^{\prime \prime}$ 'S, 4747’29,4”W, 1.013 m, 20.I.2012, R.C. Sodré et al. 03 (UFG); estrada que leva ao Vale da Lua, 6.IX.2013, P.H.B. Santos et al. 31 (UFG); $2,3 \mathrm{~km}$ de Alto Paraíso de Goiás, 30.VII.2016, M.J. Silva 7650, 7651, 7652 (UFG). Material adicional examinado: BRASIL. GOIÁS: São João d'Aliança, GO-118, à esquerda do km 82, em direção a cidade, 14'9'28,9'S, 47046'56,9'W, 1.019 m, 1.VIII.2013, M.J. Silva et al. 5173 (UFG).

Maprounea guianensis distribui-se na Bolívia, Equador, Guiana, Guiana Francesa, Panamá, Peru, Suriname e Venezuela (Esser 1999). No Brasil, só não é encontrada na região Sul (Santos \& Sales 2009, Pscheidt \& Cordeiro 2012). Neste estudo, foi coletada próximo a córregos, em borda de floresta estacional Cerrado sensu stricto e cerrado rupestre em meio à vegetação, ou próximo a rochas com flores e frutos de agosto a dezembro.

3. Microstachys anisodonta (Müll. Arg.) M.J. Silva, comb. nov. Sebastiania anisodonta Müll. Arg., Fl. bras. 11: 550. 1874. Tipo: BRAZIL. Prov. Goyaz, Serra D’Ourada, sem data, Pohl 1555 (Lectótipo, aqui designado: $\mathrm{M}$ !; isolectótipos $\mathrm{W}$ !, G!).

Fig. 2m-r

Subarbustos 55-70 $\mathrm{cm}$ alt.; ramos decumbentes, esverdeados a acinzentados, pubescente a híspidos; lâmina foliar $0,3-1,7 \times 0,2-$ $0,5 \mathrm{~mm}$, oval-lanceolada a lanceolada, base obtusa, às vezes auriculadas, ápice agudo, híspida em ambas as faces, porém os tricomas mais adensados na face abaxial; face adaxial verde-escuro, abaxial verde-opaco. Tirso 0,3-1,3 cm compr., com címulas estaminadas dísticas; brácteas pistiladas $0,6-0,7 \times 0,5-0,7 \mathrm{~mm}$, ovais, ápice agudo; brácteas estaminadas $0,3-0,5 \times 0,4-0,6 \mathrm{~mm}$, semelhantes às pistiladas; flores estaminadas $0,6-1,1 \mathrm{~mm}$ compr., pedicelo $0,1-0,2 \mathrm{~mm}$ compr., sépalas $0,3-0,7 \times$ 0,2-0,4 mm, espatuladas, ápice obtuso, margem discretamente denticulada; flores pistiladas 1,2-1,8 $\mathrm{mm}$ compr., pedicelo $0,1-0,2 \mathrm{~mm}$ compr., sépalas $0,4-0,8 \times 0,3-0,7 \mathrm{~mm}$, ovais, ápice agudo, margem denteada, ovário $0,7-1 \times 0,6-0,9 \mathrm{~mm}$, globoso com cornículos avermelhados apenas na porção superior, hispídulo, estiletes curvos. Cápsula 3-4 × 2-3 cm, globosa. Sementes 3-3,2 × 1,1-1,4 mm, cilíndricas, cinéreas, carúncula amarelada.

Material examinado: Alto Paraíso de Goiás, 24.III.1971, H.S. Irwin et al. 33098 (K, NY); estrada para Cavalcante, 8.II.1987, S.R. Neto 613 (MG); cerca de 2,8 km a partir da bifurcação da entrada que leva a Cachoeira das Sete

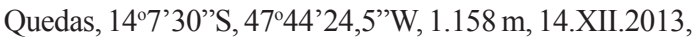
M.J. Silva et al. 5671, 5672 (UFG); cerca de 2,8 km a partir da bifurcação que leva a Cachoeira das Sete Quedas, 147'30'S, 4744'24,5"W, 1.158 m, 14.XII.2013, M.J. Silva et al. 5671, 5672 (UFG); imediações do Morro do Japonês, 142'36,5"S, 47031'43, 1'W, 1.482 m, 11.V.2013, P.H.B. Santos et al. 10, 13 (UFG). Cavalcante, em direção ao Morro Peito de Moça, cerrado rupestre, 14ㄷ' $49,9^{\prime \prime}$ 'S, 47045'5,9'W, 1.153 m, 3.VIII.2013, M.J. Silva et al. 5236 (UFG); Serra do Pouso Alto, proximidades casa abandonada acessada via cruzeiro, 13056'29,7'S, 47029'45,2”W, 5.IV.2013, R.C. Sodré et al. 688 (UFG).

Müller (1874) descreveu Sebastiania anisodonta com base na coleção Pohl 1555 proveniente da Serra Dourada, porção central do estado de Goiás, e depositada no herbário de Munique, na Alemanha. Govaerts et al. (2000) apresentaram S. anisodonta como Microstachys sp., isto é, não formalizando a nova combinação. Estudando a coleção tipo de $S$. anisodonta constatamos que a mesma melhor se enquadraria no gênero Microstachys, haja vista tratar-se de uma planta subarbustiva com inflorescências opostas às folhas, flores pistiladas corniculadas e sementes cilíndricas com carúncula em forma de chapéu, caracteres estes típicos de Microstachys. Desta forma, propomos aqui a nova combinação M. anisodonta (Müll. Arg.) M.J. Silva e sua lectotipificação em consonância com o Código Internacional de Nomenclatura Botânica, McNeill 
et al. (2012). Reiteramos que Microstachys foi reconhecido por Esser (1997) como um gênero independente de Sebastiania devido a sua diferenciada morfologia, o que também foi corroborado pela filogenia molecular sobre o gênero efetuada por Pscheidt (2015).

Microtachys anisodonta pode ser reconhecida pelo hábito decumbente, inflorescências delicadas e diminutas, folhas verde-escuras, lustrosas na face adaxial e com margem com dentes adpressos na porção proximal e curvos na distal. Sua distribuição até então é conhecida apenas para o estado de Goiás. Neste estudo, foi encontrada crescendo em cerrado rupestre ou campos rupestres próximo a fendas de rochas.

4. Microstachys bidentata (Mart. \& Zucc.) Esser, Kew Bull. 53: 958. $1998 . \quad$ Figs. 3a-g; 7d-f

Subarbustos 0,50-1,60 m alt.; ramos virgados, eretos, verdes a cinéreos, glabros; lâmina foliar 2,5-4,5 × 1,2-2 mm, linear, base cuneada, ápice agudo, margem esparsa e irregularmente serreada com discretas glândulas cilíndricas impressas, glabra a glabrescente; verde escuro em ambas as faces. Tirsos 3,6-4,2 cm compr. com címulas estaminadas dísticas; brácteas pistiladas $1-1,2 \times 0,8-1 \mathrm{~mm}$, ovais, ápice agudo; brácteas estaminadas $0,2-0,3 \times 0,1-0,23 \mathrm{~mm}$, ovais, ápice obtuso; flores estaminadas $0,8-1,3 \mathrm{~mm}$, pedicelo $0,1-0,2 \mathrm{~mm}$ compr., sépalas $0,7-0,8 \times 0,4-0,5$ $\mathrm{mm}$, espatuladas ou oboval-espatuladas, ápice obtuso, denticulada no ápice, estames livres; flores pistiladas $1-2 \mathrm{~mm}$ compr.; pedicelo $0,1-0,2 \mathrm{~mm}$ compr., sépalas $0,8-0,9 \times 0,7-0,8 \mathrm{~mm}$, ovais, ápice obtuso, margem dentada no terço superior, ovário 0,7-1,7 × 1-1,9 mm, glabro, globoso com um par de córneos avermelhados na porção superior de cada mericarpo; estiletes globosos. Cápsula $0,4-0,5$ $\times 0,3-0,4 \mathrm{~cm}$, oblonga. Sementes $3-4 \times 1,2-1,5$ $\mathrm{mm}$, subcilíndricas, enegrecidas, carúncula creme a amarelada.

Material examinado selecionado: Alto Paraíso de Goiás, entrada à esquerda em direção a Serra do Pouso Alto, 14³'43,9'S, 47³0'14”'W, 25.V.2012, R.C. Sodré et al. 116 (UFG); $2 \mathrm{~km}$ a noroeste do Morro do Buracão, 14'6'26,5"S, 47044'5,2”'W, 1.152 m, 10.V.2013, P.H.B. Santos et al. 03 (UFG); 14 $4^{\circ} 26,5^{\prime}$ 'S, 47 4 44'5,2”W, $1.152 \mathrm{~m}, 10 . \mathrm{V} .2013$, P.H.B. Santos et al. 03, 04, 05, 06, 07 (UFG); próximo ao Salto de 120 metros, $14^{\circ} 10^{\prime} 14,5^{\prime \prime} \mathrm{S}, 47^{\circ} 46^{\prime} 48,4^{\prime \prime} \mathrm{W}, 1.182 \mathrm{~m}, 12 . \mathrm{X} .2013$, P.H.B. Santos et al. 65, 66 (UFG); após o alojamento principal do Parque, $14^{\circ} 10^{\prime} 10,5^{\prime}$ 'S, 47 $47^{\circ} 47^{\prime} 29,4^{\prime \prime} \mathrm{W}, 1.013$ m, 20.I.2012, R.C. Sodré et al. 05 (UFG); próximo à vereda ao sul do rio Preto, em direção ao Cânion 1,
149,3'9”S, 47048,6'42”'W, 1.013 m, 29.IX.2012, R.C. Sodré et al. 191 (UFG); margem do rio Preto, a poucos metros do cânion I, 148,6'46”'S, 47048,3'20”'W, 961 m, 15.XII.2012, R.C. Sodré et al. 417 (UFG); sopé do Morro da Baleia, porção oeste deste, 9.II.2013, R.C. Sodré et al. 467 (UFG); cerca de $2 \mathrm{~km}$ a nordeste da casa dos pesquisadores, $14^{\circ} 7^{\prime} 57^{\prime}$ 'S, $47^{\circ} 45^{\prime} 8,8^{\prime \prime} \mathrm{W}, 1.082 \mathrm{~m}$, 21.VI.2013, R.C. Sodré et al. 783, 784, 785 (UFG); cerca de $1,5 \mathrm{~km}$ a noroeste do Morro do Buracão, 14 6'33,9"S, 47039'47,7'W, 1.144 m, 10.II.2013, M.J. Silva et al. 4714 (UFG). Cavalcante, campo úmido lateral ao Morro Peito de Moça, 2.VIII.2013, M.J. Silva et al. 5251, 5252 (UFG); $925 \mathrm{~m}$ a partir do rio Preto na área da Cachoeira das Sete Quedas, $14^{\circ} 5^{\prime} 40,9^{\prime}$ 'S, 47 $45^{\circ} 5,8^{\prime}$ 'W, $1.062 \mathrm{~m}$, 3.VIII.2013, M.J. Silva et al. 5224 (UFG).

Distribui-se em caatinga arbustiva, cerrado sensu stricto e em campos sujos ou rupestres nas regiões Norte (Amazonas, Pará, Rondônia, Roraima, Tocantins), Nordeste (Bahia, Maranhão), Centro-oeste (Distrito Federal, Goiás, Mato Grosso do Sul, Mato Grosso) e Sudeste (Minas Gerais, Rio de Janeiro, São Paulo). É de fácil reconhecimento quando comparada às demais espécies estudadas pelas folhas lineares, às vezes linear-lanceoladas, porte esguio pouco ramificado, flores pistiladas com estiletes globosos e cápsulas oblongas com córneos discretos no ápice de cada mericarpo. Pode ser confundida com $M$. salicifolia quando alguns indivíduos desta possuem folhas lineares, mas em M. salicifolia as folhas possuem margem com glândulas globoides regularmente distribuídas (vs. punctiformes, esparsa e irregularmente distribuídas em $M$. bidentata), as flores estaminadas são usualmente avermelhadas ( $v s$. esverdeadas), os estiletes são subulados (vs. globosos) e os frutos também apresentam cornículos ao longo dos carpelos ( $v s$. ápice).

5. Microstachys corniculata (Vahl) Griseb., Fl. Bri. W. I.: 49. $1859 . \quad$ Figs. 3h-o; $7 \mathrm{~g}$

Subarbustos $0,15-0,7 \mathrm{~m}$ alt.; ramos decumbentes, delicados, esverdeados, vináceos a acinzentados, glabros, pubescentes ou curtamente híspidos; lâmina foliar 1,4-4 × 0,4-1,4 cm, lanceolada a oval-lanceolada, base obtusa a cordada, ápice agudo a obtuso, glabra na face adaxial e híspida na abaxial, verde-escura na face adaxial e verde-claro ou opaca na abaxial. Tirsos 0,4-2 cm compr., com címulas estaminadas dísticas; brácteas pistiladas $0,9-1,3 \times 1,1-1,4$ $\mathrm{mm}$, ovais, ápice obtuso; brácteas estaminadas $0,7-1,1 \times 0,5-0,9 \mathrm{~mm}$, ovais a oval-lanceoladas, ápice obtuso; flores estaminadas $0,8-1,3 \mathrm{~mm}$ compr., avermelhadas, pedicelo $0,1-0,2 \mathrm{~mm}$ 


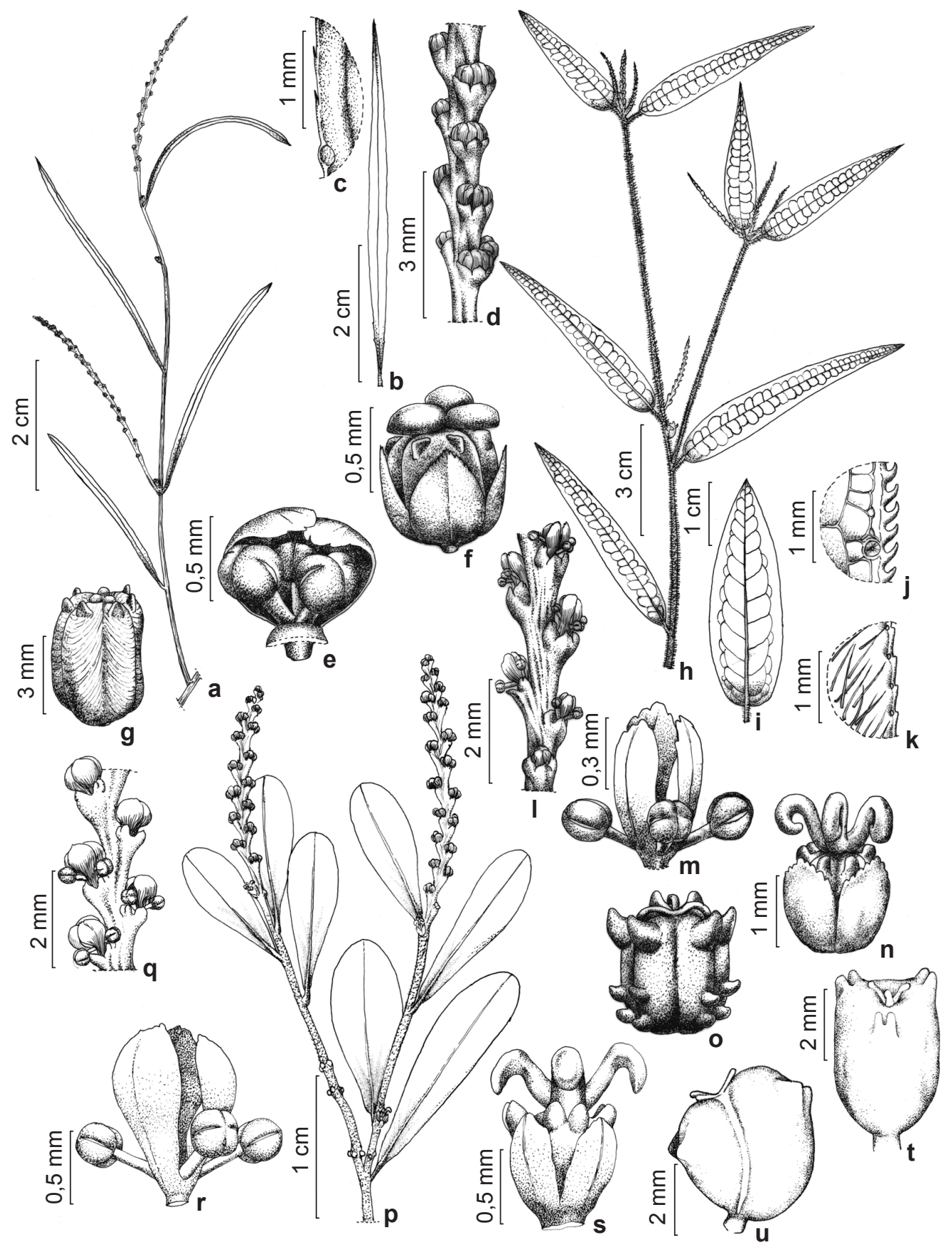

Figura 3 - a-g. Microstachys bidentata - a. ramo florido; b. folha; c. detalhe da glândula na margem da folha; d. detalhe da inflorescência mostrando as címulas estaminadas; e. flor estaminada; f. flor pistilada; g. cápsula. h-o. $M$. corniculata - h. ramo florido; i. folha; j. detalhe da porção distal da margem foliar; k. detalhe da porção proximal da margem foliar; 1. detalhe da inflorescência mostrando as címulas estaminadas; $m$. flor estaminada; $n$. flor pistilada; $o$. cápsula. p-u. M. crassifolia - p. ramo florido; q. detalhe da inflorescência mostrando as címulas estaminadas; r. flor estaminada; s. flor pistilada; t. cápsula com todos os mericarpos férteis; u. cápsula com um dos mericarpos abortados. Figure 3 - a-g. Microstachys bidentata - a. flowering branch; $b$. leaf; c. detail of the gland on leaf margin; d. detail of the inflorescence showing staminate cymules; e. staminate flower; f. pistillate flower; g. capsule. h-o. M. corniculata - h. flowering branch; i. leaf; j. detail of the distal portion of the leaf margin; $\mathrm{k}$. detail of the proximal portion of the leaf margin; 1 . detail of the inflorescence showing staminate cymules; $m$. staminate flower; n. pistillate flower, o. capsule. p-u. M. crassifolia - p. flowering branch; $q$. detail of the inflorescence showing staminate cymules; $r$. staminate flower; s. pistillate flower; t capsule with all mericarps fruitful; $u$. capsule with one of the mericarps aborted. 
compr., sépalas $0,5 \times 0,3 \mathrm{~mm}$ compr., oblongoespatuladas, ápice obtuso, margem denticulada no terço superior; flores pistiladas 2,1-2,4 mm compr., sésseis, sépalas $1,1-1,5 \times 0,5-0,9 \mathrm{~mm}$, largamente ovais, ápice obtuso, margem diminutamente lacerada no terço distal, ovário 1,8-2,1 × 1,2-1,7 $\mathrm{mm}$, subgloboso, glabro, com córneos usualmente na porção basal e distal, estiletes subulados, ascendentes e curvados apicalmente. Cápsula 5-6 × 4-6 mm, semelhante ao ovário, porém com tegumento crustáceo. Sementes 4-5 × 1,9-2,2 $\mathrm{mm}$, oblongas, enegrecidas, lustrosas, carúncula amarelada.

Material examinado: Alto Paraíso de Goiás, imediações da bifurcação da trilha que leva a região de Saltos e Corredeiras, 10.X.2013, M.J. Silva et al. 5448 (UFG); trilha divisória que leva aos Saltos e as Corredeiras, 10.X.2013, M.J. Silva et al. 5448 (UFG); próximo ao Salto de 120 metros, $14^{\circ} 9^{\prime} 91^{\prime \prime}$ 'S, 47050'93,3”'W, 520 m, 11.X.2013, P.H.B. Santos et al. 44, 46, 48 (UFG). Colinas do Sul, trilha de acesso a sede da Fazenda Gavião, 14'9'52"S, 47052'48,4”'W, 520 m, 1.XI.2013, P.H.B. Santos et al. 74, 75, 76, 78 (UFG); morro ao norte da Fazenda Gavião, 14ㅇ'25,8”'S, 4752'21,8”'W, 574 m, 12.VII.2013, P.H.B. Santos et al. 20 (UFG).

Espécie registrada desde o México até Argentina, sendo no Brasil encontrada de norte a sul em cerrado rupestre, bordas de florestas estacionais ou ombrófilas litorâneas ou não, restingas, cerrado sensu lato e campinaranas sobre solos argilosos ou arenosos.

Em decorrência de sua ampla distribuição mostra-se bastante polimórfica, mas pode ser identificada pelo seguinte conjunto de caracteres: hábito delicado, ramos glabros a curtamente híspidos, inflorescências delicadas diminutas (até 2 cm compr.), cápsulas diminutas (até $6 \mathrm{~mm}$ compr.) com tegumento crustáceo, flores estaminadas avermelhadas com sépalas denticuladas no ápice e pistiladas com estiletes ascendentes e curvos.

Entre as espécies estudadas compartilha alguns caracteres, como aspecto delicado, inflorescências e frutos diminutos com $M$. anisodonta, mas esta última além de restrita ao estado de Goiás (vs. Neotropical em $M$. corniculata), possui folhas com margens com serras impressas até a metade e curvas na porção distal (vs. apenas curvas).

6. Microstachys crassifolia M. J. Silva, Pscheidt \& Cordeiro, Nordic J. Bot. 34: 364. 2016.

Figs. 3p-u; 7h,i

Subarbustos 5-15 cm alt.; ramos cespitosos, rosados, vináceos ou avermelhados, crassos, entrenós bem evidentes; glabros a glabrescentes; lâmina foliar 1,0-2,8 × 0,3-0,7 cm, espatuladas, crassa, base cuneada, ápice obtuso a arredondado, margem inteira com glândulas punctiformes basais, glabras em ambas as faces. Tirsos 1,7-3 cm compr., avermelhados, címulas estaminadas espiraladas, avermelhados; brácteas pistilada $1 \times 1-3,1 \mathrm{~mm}$, ovais, ápice obtuso a agudo; brácteas estaminadas $0,3-0,4 \times 0,6-0,8 \mathrm{~mm}$, ovais, ápice obtuso, ambas vináceas a avermelhadas; flores estaminadas 0,8-1,4 mm compr., pedicelo 0,1-0,2 mm comp., sépalas $0,6-0,9 \times 0,4-0,5 \mathrm{~mm}$, espatuladas, ápice obtuso, margem denticulada no terço superior; flores pistiladas $1-1,3 \mathrm{~mm}$, subsésseis (pedicelo até $0,2 \mathrm{~mm}$ compr.), sépalas $0,7-0,9 \times 0,8-1 \mathrm{~mm}$, ovais, ápice obtuso, irregularmente denticulado no terço superior; ovário $0,7-0,8 \times 0,6-0,8 \mathrm{~mm}$, globoso, glabro, com córneos diminutos na porção distal; estiletes ascendentes, curvos no terço superior, glabros. Cápsula 3-5 × 2,5-3 mm, oblonga, avermelhada com diminutos córneos. Sementes 2,8-2,9 × 1,2-1,4 mm, oblongas; carúncula estipitada, amarelada.

Material examinado: Alto Paraíso de Goiás, 12.XI.1996, M.A. da Silva \& A.J.V. dos Santos 3229 (IBGE, SP); córrego no sopé da Serra do Pouso Alto, ca. $300 \mathrm{~m}$ após a casinha abandonada acessada pela entrada do cruzeiro, $13^{\circ} 57^{\prime} 42,4^{\prime \prime} \mathrm{S}, 4^{\circ} 28^{\prime} 49,9^{\prime \prime} \mathrm{W}$, 1.405 m, 6.IV.2013, M.J. Silva et al. 4824, 4825, 4826, 4827, 4828, 4829 (UFG); 30.I.2014, M.J. Silva et al. 5769, 5770 (UFG). Cavalcante, sopé da Serra do Pouso Alto após a casinha abandonada acessada pela entrada do cruzeiro, $13^{\circ} 56^{\prime} 31,3{ }^{\prime \prime} \mathrm{S}, 4^{\circ} 29^{\prime} 54,84^{\prime \prime} \mathrm{W}, 1.078 \mathrm{~m}$, 4.III.2012, M.J. Silva et al. 4126, 4127, 4128, 4129, 4130, 4131, 4132, 4133, 4134 (UFG); 1356'35”'W, 47029'42”'S, 1.452 m, 16.II.2015, M.J. Silva et al. 6471, 6472, 6473, 6476, 6477 (UFG).

Material adicional examinado: BRASIL. GOIÁS: São João d'Aliança, Chapada dos Veadeiros, XI.2007, J.F.B. Pastore et al. 2311 (HUEFS).

Espécie provavelmente endêmica da região da Chapada dos Veadeiros (Silva et al. 2016). Foi encontrada nas imediações do Morro Peito de Moça e na Serra do Pouso Alto, em campos limpos e úmidos próximos a córregos à sombra da vegetação graminoide formando populações agregadas que se destacam pela coloração rosada, vinácea ou avermelhada do caule e ramos. É reconhecida entre as demais estudadas pelo porte diminuto (5-15 cm compr.) e caule e ramos rosados. Distingue-se das demais do gênero pelas folhas com margem não serreada e ramos rosados, vináceos ou avermelhados com entrenós bem evidentes. 
7. Microstachys daphnoides (Mart.) Müll. Arg., Linnaea 32: 91. 1863.

Figs. 4a-g; $7 \mathrm{j}$

Subarbustos $0,80-1,25 \mathrm{~m}$ alt.; ramos virgados, vináceos a cinéreos, curtamente e densamente velutinos nas porções jovens, assim como ambas as faces foliares, face externa das sépalas pistiladas, brácteas de ambas as flores, eixo da inflorescência, ovário e frutos; lâmina foliar 1,2-2,6 × 0,4-2 cm, oval a oval-lanceolada, base obtusa; ápice agudo a obtuso; margem com serras curvadas, glândulas punctifomes; face adaxial verde-escura ou vináceas e opaca, abaxial verde-claro a esbranquiçada. Tirsos 1-4,1 cm compr., címulas estaminadas dísticas; brácteas pistiladas $1-1,4 \times 0,8-1 \mathrm{~mm}$, ovais, ápice obtuso; brácteas estaminadas $0,8-1,3 \times 0,3-0,4$ $\mathrm{mm}$, semelhantes às pistiladas; flores estaminadas $0,8-1,3 \mathrm{~mm}$ compr., sésseis, sépalas $0,3-1 \times 0,2-$ $0,4 \mathrm{~mm}$, espatuladas, ápice obtuso, margem inteira; flores pistiladas $1,1-1,5 \mathrm{~mm}$ compr., pedicelo $0,1-0,2 \mathrm{~mm}$ compr., sépalas $0,8-1 \times 0,9-1,2 \mathrm{~mm}$, largamente ovais, ápice agudo, margem inteira, ovário $0,4-0,7 \times 0,6-0,9 \mathrm{~mm}$, globoso, com diminutos córneos na porção superior, estiletes subulados, patentes e ligeiramente curvos no ápice, densamente velutinos. Cápsula 0,9-1 × 0,3-1 $\mathrm{cm}$, globosa, densa e curtamente velutinas com córneos orientados lateralmente na porção inferior, vestigiais na mediana e eriçados na superior. Sementes 2,8-3,2 × 2-2,8 mm, cilíndricas, enegrecidas, lustrosas, carúncula amarelada.

Material examinado: Alto Paraíso de Goiás, saltos, nas imediações da cachoeira de 120 metros, 14 ${ }^{\circ}$ '46,4"S, 47034'14,1”'W, 1.330 m, 12.X.2013, P.H.B. Santos et al. 68, 69, 70 (UFG). Cavalcante, imediações do Morro Peito de Moça, 3.VII.2013, M.J. Silva et al. 5235 (UFG); cerca de $7 \mathrm{~km}$ ao norte do Morro da Baleia, após o rio Preto, 142'57,3"S, 47³9'34,7'W, 3.VII.2013, R.C. Sodré et al. 827,828 (UFG).

Registrada para o Brasil e Paraguai, sendo no primeiro país encontrada de norte a sul, mas bastante variável em altura e vestimenta dos ramos e folhas. Cresce em cerrado rupestre próximo a afloramento de rochas, cerrado sensu stricto, campos rupestres ou sujos, e também em áreas abertas de florestas estacionais ou cerradão. Coletada em cerrado rupestre próximo a afloramento de rochas e em cerrado sensu stricto.

Apesar de amplamente distribuída, pode ser reconhecida e distinta das demais congêneres estudadas, pelo caule, ramos e folhas densa e curtamente velutinos, os tricomas canescentes, margem das folhas com serras curvas ou retas, flor pistilada com sépalas e estiletes densamente velutinos, estes últimos patentes e com ápices ligeiramente curvos, e frutos com córneos inferiores orientados lateralmente, os medianos vestigiais e os superiores eriçados.

Pode ser confundida também com $M$. hispida pelo porte virgado, ramos indumentados e flores pistiladas com face externa das sépalas, ovário e estiletes indumentados. No entanto, em M. hispida as serrulas da margem foliar são adpressas (vs. curvas e eretas em $M$. daphnoides), os estiletes são conspicuamente curvados e voltados para trás ( $v s$. patentes), a face abaxial das folhas é pubescente ( $v s$. velutina) e os frutos possuem córneos inferiores e superiores curvados para cima (córneos inferiores orientados lateralmente, os medianos vestigiais e os superiores eriçados).

8. Microstachys ditassoides (Didr.) Esser, Kew Bull. 53: 958. 1998.

Figs. 4h-n; 8a-d

Subarbustos 11-70 cm alt.; com xilopódio bastante desenvolvido; ramos cespitosos, eretos, sublenhosos, esverdeados a acinzentados, glabros a densamente tomentelos; lâmina foliar 0,9-1,6 $\times 0,4-0,5 \mathrm{~cm}$, séssil, ovais a oval-triangulares, às vezes cordiforme, base cordada, ápice obtuso, glabras a densamente pubescentes na face adaxial e tomentosas a vilosas na face abaxial; face adaxial verde-escuro, face abaxial verde-clara a esbranquiçada, margem revoluta com glândulas punctiformes basais. Tirsos 1-5,5 cm compr., címulas estaminadas espiraladas; brácteas pistiladas $1-1,7 \times 0,6-0,8 \mathrm{~mm}$, ovais, ápice obtuso; brácteas estaminadas $0,5-0,3 \mathrm{~mm} \times 0,1-0,3 \mathrm{~mm}$, ovais, ápice agudo; flores estaminadas $1-1,2 \mathrm{~mm}$ compr., sésseis; sépalas $0,4 \times 0,2 \mathrm{~mm}$, espatuladas, ápice obtuso, margem denticulada no terço superior; flores pistiladas $0,8-1,2 \mathrm{~mm}$, pedicelo $0,1-0,2$ $\mathrm{mm}$ compr, sépalas $0,9-1,2 \times 0,4-0,5 \mathrm{~mm}$, ovais a oval-elípticas, ápice obtuso, margem denteada, ovário $0,8-1,8 \times 1-1,8 \mathrm{~mm}$, globoso com diminutos córneos avermelhados desde a metade ao ápice. Cápsulas 4,8-5 × 6-6,5 mm, globosas, pubescentes, semelhantes ao ovário. Sementes $2,8-3,2 \times 2-2,8$ $\mathrm{mm}$, oblongas, enegrecidas, lustrosas; carúncula séssil ou estipitada, amarelada.

Material examinado: Alto Paraíso de Goiás, entrada para o Povoado São Jorge, 7.IX.2013, P.H.B. Santos et al. 34 (UFG); em direção ao rio Preto, 15.XII.2012, R.C. Sodré et al. 412 (UFG); imediações do rio Preto, 148'51,6”'S, 47048'32,6”W, 1.025 m, 27.X.2012, R.C. Sodré et al. 274 (UFG); cerca de $1 \mathrm{~km}$ a partir do rio Preto, em direção ao alojamento, 27.XII.2012, R.C. Sodré et al. 274 (UFG); morros ente o alojamento do PNCV e o cânion I do rio Preto, 15.XII.2012, R.C. Sodré et al. 414 (UFG). 


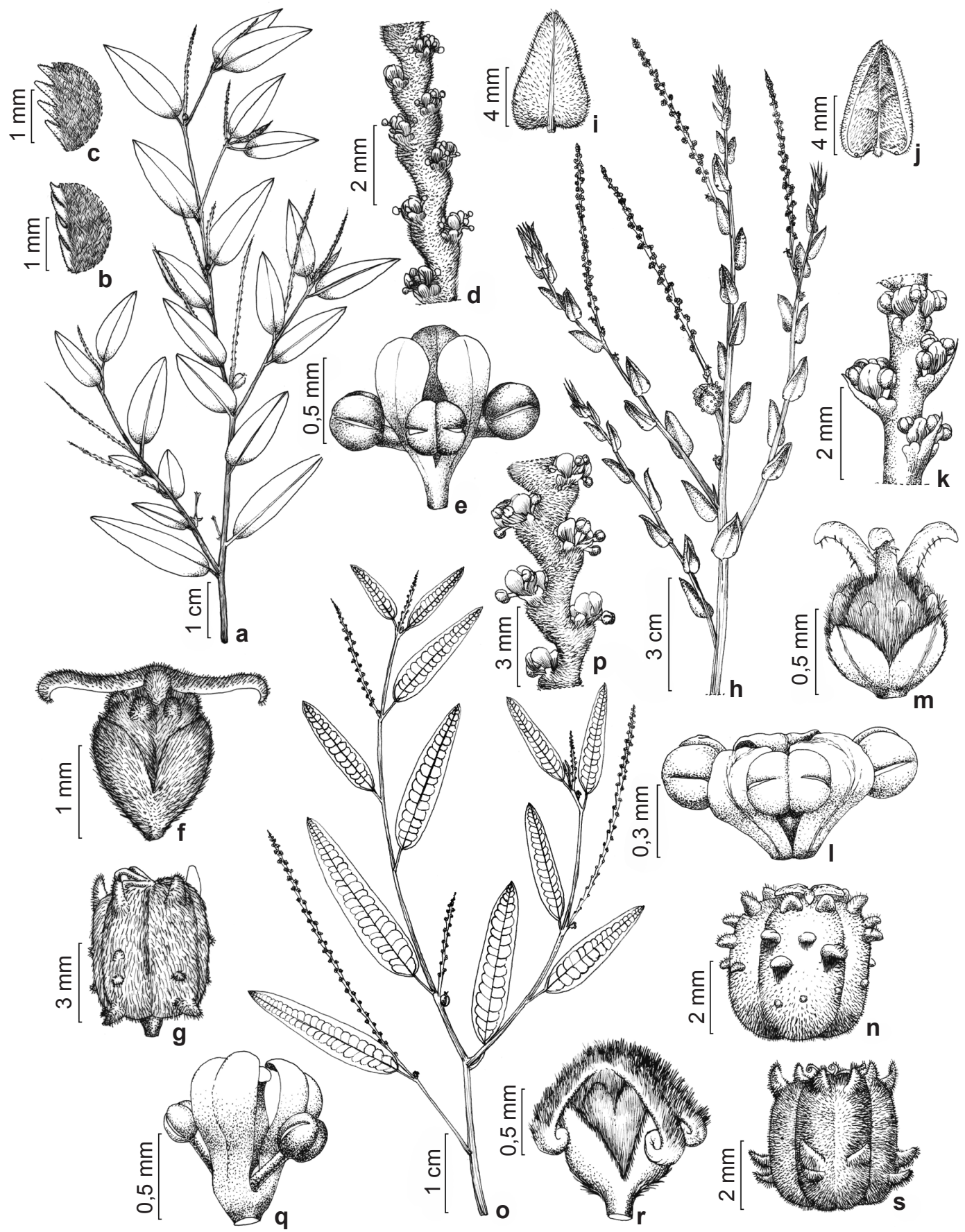

Figura 4 - a-g. Microstachys daphnoides - a. ramo florido; b. detalhe da porção proximal da margem foliar; c. detalhe da porção distal da margem foliar; d. detalhe da inflorescência mostrando as címulas estaminadas; e. flor estaminada; $\mathrm{f}$. flor pistilada; g. cápsula. h-o. M. ditassoides - h. ramo florido; i. face adaxial da folha; j. face abaxial da folha; k. detalhe da inflorescência mostrando as címulas estaminadas; 1. flor estaminada; m. flor pistilada; n. cápsula. o-s. M. hispida - o. ramo florido; . detalhe da inflorescência mostrando as címulas estaminadas; q. flor estaminada; r. flor pistilada; s. cápsula. Figure 4 - a-g. Microstachys daphnoides - a. flowering branch; b. detail of the proximal portion of the leaf margin; c. detail of the distal portion of the leaf margin; d. detail of the inflorescence showing staminate cymules; e. staminate flower; f. pistillate flower; g. capsule. h-o. $M$. ditassoides - h. flowering branch; i. adaxial surface of the leaf; $\mathrm{j}$. abaxial surface of the leaf; $\mathrm{k}$. detail of the inflorescence showing staminate cymules; 1. staminate flower; m. pistillate flower; n. capsule. o-s. $M$. hispida - o. flowering branch; p. detail of the inflorescence showing staminate cymules; q. staminate flower; r. pistillate flower; s. capsule. 
Espécie reportada para Bahia, Goiás, Minas Gerais, São Paulo e Piauí (Silva \& Esser 2011). Coletada em diversas fitofisionomias do PNCV, sendo mais frequente no cerrado rupestre e nos campos sujos e rupestres sobre solos litólicos ou argilo-pedregosos com flores e frutos de outubro a dezembro.

Por possuir folhas sésseis conspicuamente cordadas com margem revoluta e um par de glândulas punctiformes basais, hábito cespitoso e um xilopódio bastante desenvolvido, $M$. ditassoides não é confundida com nenhuma das espécies estudadas.

9. Microstachys hispida (Mart. \& Zucc.) Govaerts, World Checkl. Bibliogr. Euphorbiaceae: 1190. 2000.

Fig. 4o-s

Subarbustos 60-90 cm alt.; ramos esverdeados a acinzentados, densamente pubescente a híspidos; lâmina 1-5,6 × 0,3-1,9 cm, lanceolada a ovallanceolada, base obtusa a arredondada; ápice agudo a obtuso, densamente pubescentes em ambas as faces; verde-clara na face adaxial e verde-esbranquiçado na face abaxial, margem com serras adpressas e discretas glândulas globosas. Tirsos 2,5-4,6 cm compr., densamente pubescentes, címulas estaminadas dísticas; brácteas pistiladas $1-1,6 \times 0,8-1,3 \mathrm{~mm}$, ovais, ápice agudo; brácteas estaminadas $0,2-1 \times 0,1-0,7 \mathrm{~mm}$, ovais, ápice obtuso a agudo; flores estaminadas $0,7-1,2 \times$ $0,5-0,7 \mathrm{~mm}$, pedicelo $0,1-0,2 \mathrm{~mm}$ compr., sépalas $0,7-0,8 \times 0,3-0,4 \mathrm{~mm}$, espatuladas, ápice obtuso, margem inteira; flores pistiladas $1-2,8 \mathrm{~mm}$ compr., pedicelo $0,1-0,2 \mathrm{~mm}$ compr, sépalas $0,8-1 \times 0,8$ $\mathrm{mm}$, ovais, ápice obtuso, margem denticulada; ovário $0,6-1,5 \times 1-1,8 \mathrm{~mm}$, globoso, pubescente, córneos diminutos; estiletes subulados fortemente curvados e pubescentes. Cápsula $0,3-0.4 \times 2,7-0,4$ $\mathrm{mm}$, globosa, densamente pubescente com córneos basais e apicais encurvados para cima. Sementes $3,6-4 \times 1,3-2 \mathrm{~mm}$, oblongas, enegrecidas, lustrosas, carúncula amarelada.

Material examinado: Alto Paraíso de Goiás, sopé do Morro da Baleia, porção oeste deste, 9.II.2013, R.C. Sodré et al. 466 (UFG). Cavalcante, estrada de Cavalcante em direção a Colinas do Sul, 1351'13'S, 4747’31,3”W, 1.005 m, 29.I.2014, P.H.B. Santos et al. 111 (UFG); limites nordeste do parque nas proximidades da GO-118, 135' $37^{\prime \prime}$ S, 47²5'56”'W, $1.467 \mathrm{~m}$ 14.XII.2012, R.C. Sodré et al. 390 (UFG); margem do rio Preto, a leste do cânion I, $14^{\circ} 8,646^{\prime}$ 'S, $47^{\circ} 48,320^{\prime} \mathrm{W}$, 961 m, 15.XII.2012, R.C. Sodré et al. 416 (UFG).

Espécie da América do Sul com registro na Argentina, Brasil, Bolívia e Paraguai (Santos
\& Sales 2009). No Brasil é encontrada em todas as regiões crescendo principalmente em campo rupestre e cerrado sensu lato (Santos \& Sales 2009; Pscheidt \& Cordeiro 2011).

Microstachys hispida assemelha-se morfologicamente a $M$. daphnoides pelos ramos, folhas, flores pistiladas e frutos indumentados e inflorescências longas (2,5-4,6 cm compr.). No entanto, em $M$. hispida as serrulas da margem foliar são adpressas ( $v s$. curvas ou eriçadas em M. daphnoides), o caule é híspido e pubescente (vs. densa e curtamente velutino), as folhas são pubescentes em ambas as faces (velutinas), os estiletes são encurvados sobre o ovário ( $v s$. patentes).

10. Microstachys salicifolia (Mart. \& Zucc.), M.J. Silva comb. nov. Cnemidostachys salicifolia Mart. \& Zucc., Nov. Gen. Sp. Pl. 1: 70. $1824 . \quad$ Fig. 5a-g 三Sebastiania corniculata fo. salicifolia (Mart. \& Zucc.) Müll. Arg., Prodr. 15: 1171. 1866.

ESebastiania corniculata var. salicifolia (Mart. \& Zucc.) Müll. Arg., Fl. bras. 11: 556. 1874.

三Sebastiania salicifolia (Mart. \& Zucc.) Pax, Pflanzenr. 4, Fam. 147. 103. 1912.

三Sebastiania salicifolia var. genuina Pax, Pflanzenr. 4, Fam. 147. 104. 1912., nom. inval. Tipo: BRAZIL. Minas Gerais: 1835, Martius s.n. (holótipo M!; isótipos E!, M!).

Subarbustos $70-80 \mathrm{~cm}$ alt.; ramos cespitosos, cilíndricos, delicados, eretos, virgados, lustrosos, esverdeados a vináceos, glabros a glabrescentes; lâmina foliar 3-5,2 × 0,1-0,6 cm, lanceoladas a oval-lanceolada, margem com diminutas serrulas adpressas e glândulas punctiformes regularmente distribuídas, base obtusa ou truncada, ápice agudo, glabras a glabrescentes em ambas às faces; face adaxial verde-escura e lustrosa, abaxial verde-clara, opaca. Tirsos 2,4-4,2 cm compr., com címulas estaminadas dísticas; brácteas pistiladas $0,3 \times 0,2$ $\mathrm{mm}$, ovais, ápice obtuso; brácteas estaminadas $0,2-0,3 \times 0,1-0,2 \mathrm{~mm}$, ovais, ápice agudo; flores estaminadas $1,4-4 \mathrm{~mm}$ compr. pedicelo $0,8-3 \mathrm{~mm}$ compr., sépalas $0,4-1 \times 0,2-0,5 \mathrm{~mm}$, espatuladas, ápice obtuso a arredondado, margem denticulada, estames livres; flores pistiladas $1-2 \mathrm{~mm}$, pedicelo $0,1-0,7 \mathrm{~mm}$ compr., sépalas $0,4-0,6 \times 0,2-0,4 \mathrm{~mm}$, ovais, ápice agudo, margem denticulada, ovário 3-4 × 1,4-3 mm compr., globoso, glabro, com diminutos córneos na base e desde o terço superior até o ápice, estiletes subulados, glabros e curvados sobre o ovário. Cápsula 4-5×3-5 mm, semelhante ao ovário, mas com córneos orientados para cima 


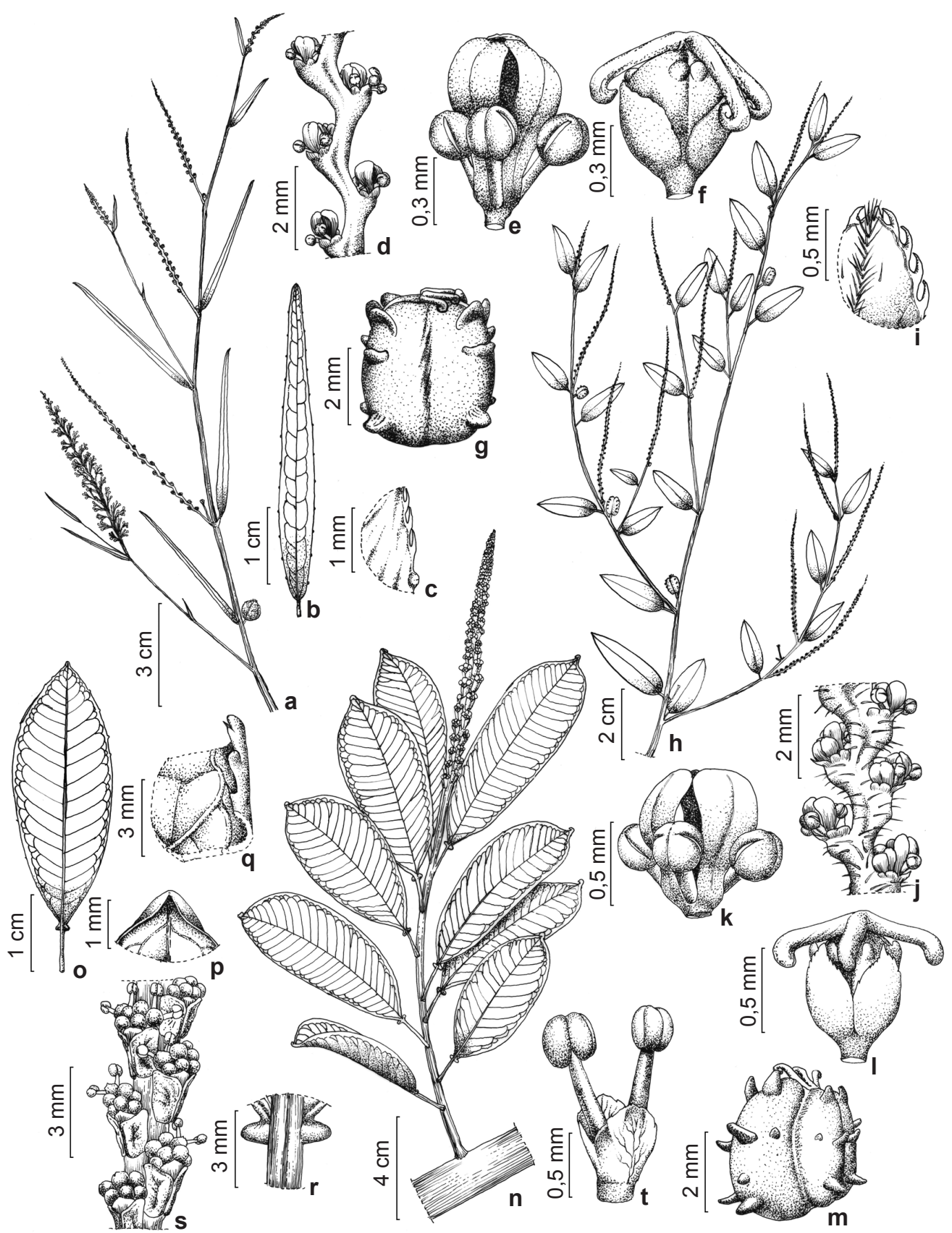

Figura 5 - a-g. Microstachys salicifolia - a. ramo florido; b. folha; c. detalhe da glândula na margem da folha; d. detalhe da inflorescência mostrando as címulas estaminadas; e. flor estaminada; f. florpistilada; g. cápsula. h-m. M. serrulata-h. ramo florido; i. detalhe da margem foliar; j. detalhe da inflorescência mostrando as címulas estaminadas; $\mathrm{k}$. flor estaminada; 1. flor pistilada; m. cápsula. n-t. Sapium haematospermum - n. ramo florido; o. folha; p. ápice foliar; q. detalhe das glândulas na margem foliar; r. detalhe das glândulas no ápice do pecíolo; s. detalhe da inflorescência mostrando as címulas estaminadas; t flor estaminada. Figure 5 - a-g. Microstachys salicifolia - a. flowering branch; b. leaf; c. detail of the gland on the leaf margin; d. detail of the inflorescence showing staminate cymules; e. staminate flower; f. pistillate flower; g. capsule. h-m. M. serrulata - h. flowering branch; i. detail of the leaf margin; j. detail of the inflorescence showing staminate cymules; k. staminate flower; 1. pistillate flower; m. capsule. n-t. Sapium haematospermum - n. flowering branch; o. leaf; p. apex leaf. q. detail of the glands on the leaf margin; r. detail of the glands in the apex of the petiole; s. detail of the inflorescence showing staminate cymules; $t$. staminate flower. 
e avermelhados. Sementes 3-4 × 1,2-1,5 mm, subcilíndricas, enegrecidas, lustrosas, carúncula amarelada.

Material examinado: Alto Paraíso de Goiás, PNCV, $13^{\circ} 15^{\prime}$ 'S, 41 ${ }^{\circ} 53^{\prime}$ W, 1.200 m, 28.XII.1991, R.M. Harley et al. 50526 (CEPEC, HUEFS, K, SP, SPF); cerca de $1 \mathrm{~km}$ a noroeste do Morro do Buracão, 146'32,4'’S, 4744'1,5"W, 1.162 m, 10.V.2013, P.H.B. Santos et al. 01, 02 (UFG); a noroeste do Morro do Buracão, 146'44,1"'S, 4743'44,8'W, 1.157 m, 10.II.2013, R.C. Sodré et al. 490 (UFG); próximo ao Salto de 120 metros, 14'10'14,5”S, 4746'48,4”W, 1.182 m, 12.X.2013, P.H.B. Santos et al. 64 (UFG); imediação do Morro do Japonês, 149'19,7'S, 47³7'4’W, 1.136 m, 22.XI.2013, P.H.B. Santos et al. 90, 92 (UFG); a direita do $\mathrm{km} 156$ da GO-118, sentido São João da Aliança a Alto Paraíso de Goiás, nas proximidades da Fazenda Rosmarine, 14'12'48,4"S, 47²9'17,1'W, 1.189 m, 15.II.2013, R.C. Sodré et al. 521, 523, 529 (UFG). Cavalcante, imediações da Cachoeira das Sete Quedas, 2.VIII.2013, R.C. Sodré et al. 817 (UFG); trecho arenoso de mata de galeria do lado direito do Rio Preto em Cavalcante, 14ㄱ'25,2'S, 47054'44,3”W, 493 m, 4.VIII.2013, M.J. Silva et al. 5276 (UFG).

Material examinado adicional. BRASIL. GOIÁS: Alexânia, km 78 da BR-060 sentido Anápolis, 250'S, $55^{\circ} 55^{\prime} \mathrm{W}, 1.000 \mathrm{~m}, 13$.XII.1982, W. Hahn et al. 870 (MO, SP). Cavalcante, cerca de $4,5 \mathrm{~km}$ da Vila Veneno em direção a São Félix, $13^{\circ} 32^{\prime}$ S, 41 ${ }^{\circ} 54^{\prime} \mathrm{W}$, 1.250 m, 17.XII.1988, R.M. Harley et al. 25585 (SP). Mossâmedes, Serra Dourada, 27.XI.1984, R.M. Harley et al. 6503 (SP, SPF). Niquelândia, oeste da Serra Negra, 16037'S, 4256'W, 850 m, 12.X.1988, R.M. Harley et al. 25038 (SP).

Cnemidostachys salicifolia foi descrita por Martius \& Zuccarini, em 1824, com base na coleção Martius s.n., proveniente de "Villa Rica Provinciae Minas Geraes", Brasil, cujas duplicatas são encontradas no herbário $\mathrm{M}$ e no herbário $\mathrm{E}$. Posteriormente, Müller $(1866,1874)$ subordinou $C$. salicifolia Martius \& Zuccarini como um sinônimo de Sebastiania corniculata Vahl, o que também foi corroborado por Pax e Hoffmann (1912), ambos sem nenhuma justificativa de fazê-lo. Esser (1998), provavelmente após Webster (1994) ter indicado que Microstachys era um gênero distinto de Sebastiania Spreng., restabeleceu Microstachys, mas, corroborou com a posição de Müller (1866, 1874) em considerar Cnemidostachys salicifolia como um sinônimo de Sebastiania corniculata, decisão também apoiada por Govaerts et al. (2000). Analisando a coleção typus de Cnemidostachys salicifolia verificamos que esta última espécie foi interpretada equivocadamente como sinônimo de M. corniculata e, portanto, resolvemos restabelecêla e combiná-la ao gênero Microstachys.
Microstachys salicifolia é reconhecida pelos ramos virgados delicados, glabros e vináceos ou verde-vináceos juntamente com o pecíolo; folhas glabras e usualmente lanceoladas com diminutas serras adpressas e glândulas punctiformes regularmente distribuídas pela margem, além de eixos da inflorescência e flores estaminadas, incluindo estames vináceos. Pode ser confundida com $M$. bidentata pelas folhas estreitas e aspecto delicado do hábito e ramos. No entanto, apresenta estiletes globosos, enquanto que em $M$. salicifolia estes são subulados e curvados sobre o ovário.

Apesar de M. salicifolia ter sido interpretada como uma variação morfológica de $M$. corniculata como supracitado e apesar desta última ser bastante polimórfica, $M$. salicifolia difere seguramente dela, pois $M$. corniculata inclui plantas decumbentes, muito delicadas, com inflorescências de 0,3-2 cm compr., delgadas, folhas usualmente largamente ovais ou mais raramente oval a elípticas ou combinações destas com base conspicuamente cordadas e margem com serras muito expressivas e curvas, enquanto $M$. salicifolia é uma espécie ereta, virgada, cespitosa, com tirsos variando de 2,4-4,2 cm compr. e folhas de base obtusa ou truncada, com forma linear ou lanceolada e margem de serrulas adpressas.

Microstachys salicifolia distribui-se pelas regiões Nordeste, Centro-Oeste e Sudeste crescendo em campos rupestres, campos sujos, áreas abertas do Cerrado sensu stricto e rupestres sobre solos arenosos ou areno-argilosos. Foi coletada nas proximidades do morro do Buracão e nas imediações da Fazenda Gavião em campos sujos e cerrado sensu stricto.

11. Microstachys serrulata (Mart.) Mull. Arg., Linnaea 32: 90. $1863 . \quad$ Figs. 5h-m; 8e,f

Subarbustos 0,5-1,6 m alt.; ramos virgados, eretos, esverdeados a acinzentados, pubescentes; lâmina foliar 0,8-5 × 0,3-1,9 cm, oval-lanceolada a lanceoladas, base obtusa a ligeiramente cordada; ápice obtuso ou agudo, glabra a glabrescente na face adaxial e pubescente na face abaxial; verde-escura na face adaxial e verde-clara na abaxial, margem com conspícuas serrulas curvas e discretas glândulas. Tirsos 2,4-4,8 cm compr., raque principal vermelha e flores estaminadas amareladas, címulas estaminadas dísticas; brácteas pistiladas $0,8-1,2 \times 0,8-1,3 \mathrm{~mm}$, ovais, ápice agudo; brácteas estaminadas $0,8-1,2 \times 0,6-0,8$ $\mathrm{mm}$, ovais a oval-lanceoladas, ápice agudo; flores estaminadas 1,1-1,4 mm compr., pedicelo 
0,1-0,2 mm compr., sépalas $0,4 \times 0,3 \mathrm{~mm}$ compr., espatuladas, ápice obtuso a arredondado, margem inteira; flores pistiladas $1-1,4 \mathrm{~mm}$ compr., pedicelo $0,1-0,2 \mathrm{~mm}$ compr., sépalas $0,4-0,5 \times 0,4-0,8 \mathrm{~mm}$, ovais, ápice agudo, margem denticulada desde o meio ao ápice, ovário 1-1,3 × 0,6-1 mm, globoso, com diminutos córneos avermelhados, glabro; estilete subulados, patentes, glabros. Cápsulas 3,9$4 \times 3-4 \mathrm{~mm}$, globosas, glabras, avermelhada com córneos diminutos, avermelhados ou amarelados irregularmente distribuídos e usualmente com um dos carpelos reduzidos ou abortado. Sementes 3-4 $\times 2-2,4 \mathrm{~mm}$, oblongas, enegrecidas, lustrosas; carúncula esbranquiçada.

Material examinado: Alto Paraíso de Goiás, lateral

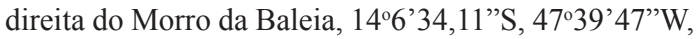
1.335 m, 9.II.2013, M.J. Silva et al. 4691 (UFG); sopé do Morro da Baleia, porção oeste deste, 9.II.2013, R.C. Sodré et al. 465 (UFG); proximidades da Cachoeira do Salto das Corredeiras, $14^{\circ} 10^{\prime} 24,8^{\prime \prime} \mathrm{S}, 47^{\circ} 49^{\prime} 31,7^{\prime \prime} \mathrm{W}$, 979 m, 8.III.2013, M.J. Silva et al. 4772, 4773 (UFG).

Material examinado adicional: BRASIL. GOIÁS: Cavalcante, Chapada dos Veadeiros, entrada para o Engenho II, Comunidade Kalunga, 7.III.2013, M.J. Silva et al. 4755 (UFG).

Ocorre no Paraguai e Brasil, sendo neste último registrada para todas as regiões (Pscheidt $\&$ Cordeiro 2011), crescendo usualmente em cerrado sensu lato. Assemelha-se a M. hispida e $M$. daphnoides pelo aspecto geral dos ramos e folhas, mas se diferencia destas e é reconhecida pelos tirsos com raque vermelha, folhas com margem com conspícuas serrulas curvas; flores pistiladas e frutos glabros com numerosos córneos irregularmente distribuídos e em geral com um dos lóculos abortados.

12. Sapium glandulosum (L.) Morong, Ann. New York Acad. Sci. 7: 227. 1893. Figs. 5n-t; 8g-i Arbustos ou árvores 1,2-3 m alt.; ramos sublenhosos, esverdeados a amarronzados, subcrassos a vináceos ou rosados nas partes jovens, glabros; estípulas triangulares, menores que $3 \mathrm{~mm}$, laceradas ou denticuladas, pecíolo $0,5-1,3 \mathrm{~cm}$ compr., ligeiramente sulcado acima, com glândulas cilíndricas patentes, opostas; lâmina foliar 2,5-7,6 $\times 1,2-3,3 \mathrm{~cm}$, oblonga, oblongo-elíptica a oblongooboval ou elípticas, base obtusa, ápice cuculadoinflexo; margem ligeiramente revoluta com esparsas glândulas e serras; nervuras secundárias perpendiculares em relação a principal, pouco proeminentes na face abaxial. Tirsos $6,1-10,8$ $\mathrm{cm}$ compr.; címulas estaminadas 6 ou 7-floras, brácteas pistiladas $1-1,2 \times 0,8-1 \mathrm{~mm}$, obtruladas, ápice obtuso margem discretamente denticulada, glândulas $1,8-2,3 \times 1,5 \mathrm{~mm}$, arredondadas; brácteas estaminadas $1,2-2 \times 2,1-2,6 \mathrm{~mm}$, obtruladas, ápice obtuso, margem discretamente denticulada, glândulas arredondadas 1,8-2,3 × $1,5 \mathrm{~mm}$; flores estaminadas $1,6-3 \mathrm{~mm}$ compr., pedicelo $0,1-0,3 \mathrm{~mm}$ compr., sépalas 2 , unidas na base com lobos obtusos, côncavos e irregularmente serreados, estames com anteras globosas; flores pistiladas $0,7-2,3 \mathrm{~mm}$ compr., sésseis; cálice com lobos obtusos; ovário 2-3-carpelar e 2-3-locular, estiletes 3, unidos, avermelhados na superfície estigmática. Cápsula 0,9-1,4×0,8-1,1 cm, globosa, enegrecida, columela trifacetada. Sementes 5,5-7,2 $\times 4,8-6,7 \mathrm{~mm}$, ovoides.

Material examinado: Alto Paraíso de Goiás, próximo à cachoeira Salto de 120 metros, 14'9'29,4"S, 47³4'3"W, 1.220 m, 12.X.2013, P.H.B. Santos et al. 59, 60, 61 (UFG); imediações do mirante do Morro da Baleia, 14'9'20,1'S, 47³8'7,5”'W, 1.145 m, 25.X.2012, R.C. Sodré et al. 60 (UFG).

Sapium glandulosum repete a distribuição do gênero, mas não é encontrada nas Antilhas (Burger \& Huft 1995; Kruijt 2010). No Brasil cresce do Oiapoque ao Chuí, associado a áreas sâvanicas (cerrado sensu stricto e rupestre) Cerradão, e florestas estacionais litorâneas ou interioranas, incluindo caatinga. $\mathrm{Na}$ área estudada foi coletada em cerradão com flores em outubro.

Dentre as espécies estudadas é a de mais fácil reconhecimento pelo hábito arborescente, folhas com ápice cuculado-inflexo, margem ligeiramente revoluta, nervuras secundárias usualmente perpendiculares em relação a principal e pecíolo com glândulas cilíndricas e patentes.

13. Sapium haematospermum Müll. Arg., Linnaea 34: 217. $1865 . \quad$ Figs. 6a-g; 9a-c

Subarbustos $62-70 \mathrm{~cm}$ alt.; ramos eretos, cespitosos, esverdeados, castanhos a avermelhados, crassos nas porções jovens; estípulas 1,2-1,4 $\mathrm{mm}$ compr., triangulares a oval-triangulares, margem denticulada; pecíolo 2,5-4 mm compr. com glândulas globosas e usualmente na face superior, opostas; lâmina foliar 4,2-6,5 × 0,7-2,4 $\mathrm{cm}$, linear a oblanceolada, base obtusa, ápice obtuso, às vezes curto acuminados, não cuculado; margem minutamente serreada e com numerosas glândulas globosas regularmente distribuídas; nervuras secundárias arqueadas em relação a principal, pouco proeminente na face abaxial. Tirsos 2,7-3 cm compr., címulas estaminadas 5-7-floras; brácteas pistiladas 1,3-1,8 × 1,5-2 $\mathrm{mm}$, largamente truladas, minutamente laceradas 


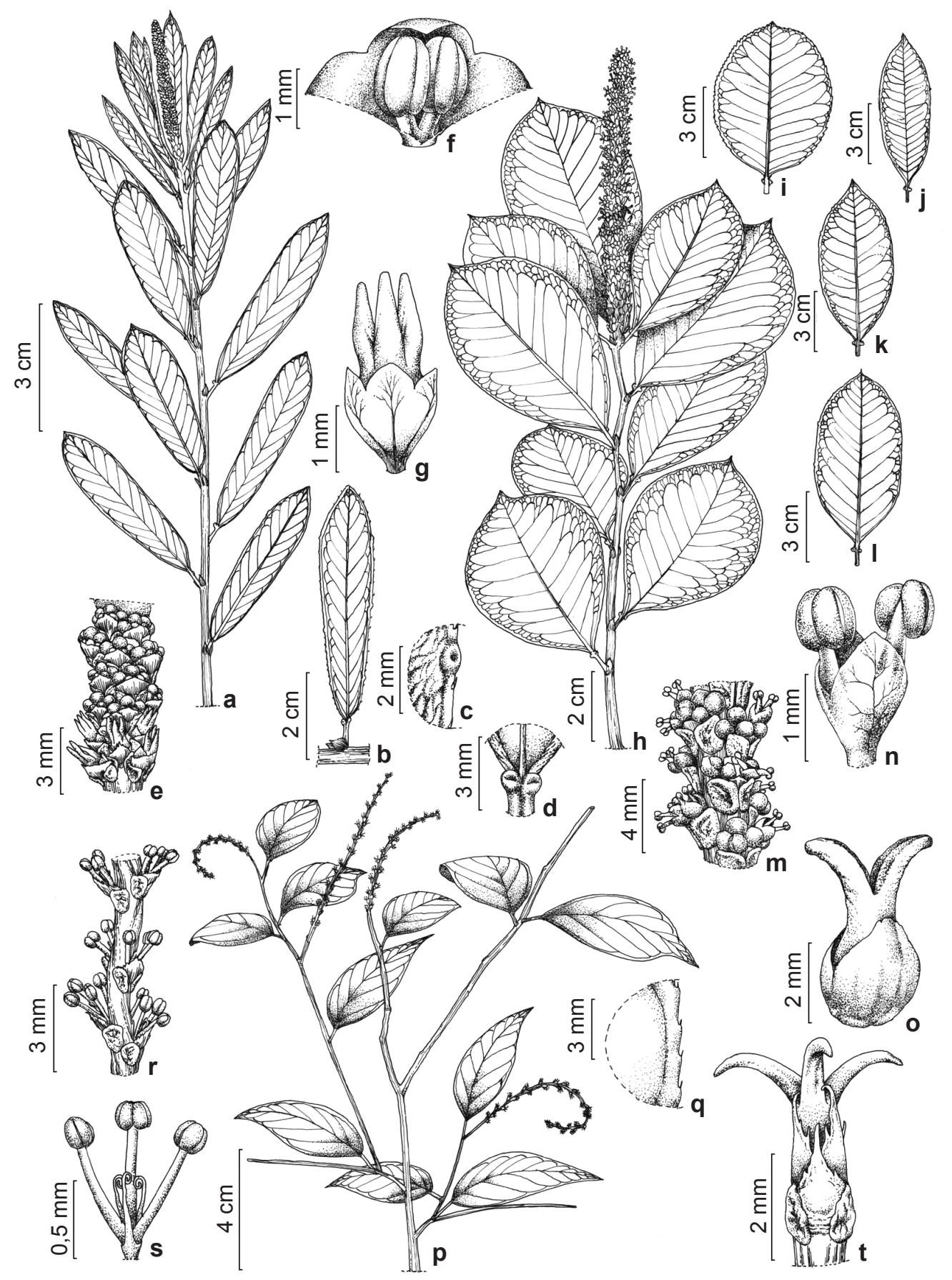

Figura 6 - a-g. Sapium glandulosum - a. ramo florido; b. folha; c. detalhe das glândulas na margem foliar; d. detalhe das glândulas no ápice do pecíolo; e. detalhe da inflorescência mostrando as flores pistiladas e as címulas estaminadas; f. flor estaminada; g. flor pistilada. h-o. Sapium obovatum - h. ramo florido; i-l. diversas formas das folhas; $\mathrm{m}$. detalhe da inflorescência mostrando as címulas estaminadas; $\mathrm{n}$. flor estaminada; o. flor pistilada. p-t. Sebastiania brasiliensis - p. ramo florido; q. detalhe da margem foliar; r. detalhe da inflorescência mostrando as címulas estaminadas; $s$. flor estaminada; $t$. flor pistilada. Figure 6 - a-g. Sapium glandulosum - a. flowering branch; b. leaf; c. detail of the glands on the leaf margin; d. detail of the glands in the apex of the petiole; e. detail of the inflorescence showing pistillate flowers and staminate cymules; f. staminate flower; g. pistillate flower. h-o. Sapium obovatum - h. flowering branch; i-l. shapes of leaves; $m$. detail of the inflorescence showing staminate cymules; $n$. staminate flower; o. pistillate flower. p-t. Sebastiania brasiliensis - p. flowering branch; q. detail of the leaf margin; r. detail of the inflorescence showing staminate cymules; s. staminate flower; t pistillate flower. 
na margem, glândulas arredondadas $0,7-0,8 \mathrm{~mm}$ diam.; brácteas estaminadas 1,7-2,3 × 1,6-1,9 $\mathrm{mm}$, semelhante à estaminada, mas com margem subinteira a ligeiramente denticulada, ápice obtuso. Flores estaminadas 2,9-3,2 mm compr., pedicelo 0,1-0,3 mm compr., sépalas 3 , lobos menores ca. 1,2 mm compr., inteiro, anteras globosas, estames usualmente menores que o cálice; flores pistiladas 3,7-4,3 mm compr., sésseis, cálice com lobos obtusos a arredondados de margem inteira; ovário $3,6 \times 1,2-1,5 \mathrm{~mm}$, glabro, estiletes eretos. Cápsulas e sementes não vistas.

Material examinado: Alto Paraíso de Goiás, próximo à sede do Parque, 149'30,6”S, 4704'38,3”'W, $1.086 \mathrm{~m}$, 10.III.2012, R.C. Sodré et al. 73, 87 (UFG); a noroeste do Morro do Buracão, 15.II.2013, R.C. Sodré et al. 514 (UFG); estrada para a Cachoeira do Abismo em cerrado ralo, 14¹1'0,8'S, 4751'8,64' $\mathrm{W}, 950 \mathrm{~m}, 21 . \mathrm{I} .2012$, R.C. Sodré et al. 31 (UFG).

Material adicional examinado: BRASIL. DISTRITO FEDERAL: Planaltina, entre Planaltina e Água Fria de Goiás, 12.XII.2013, M.J. Silva et al. 5623 (UFG).

Espécie sulamericana (Brasil, Bolívia, Paraguai, Argentina e Uruguai), segundo Kruijt (2010). BFG (2015) citaram-na para o cerrado sensu lato e florestas pluviais das regiões CentroOeste (Mato Grosso), Sudeste (Rio de Janeiro) e Sul (Paraná, Santa Catarina). Sua distribuição é aqui ampliada para o estado de Goiás, onde cresce no cerrado ralo e no cerrado sensu stricto.

Diferencia-se das demais congêneres pelo hábito subarbustivo até $70 \mathrm{~cm}$ alt., folhas lineares a oblanceoladas com margem minutamente serreada e com numerosas glândulas globosas regularmente distribuídas, pecíolo com glândulas globosas em sua face superior, flores pistiladas com estiletes eretos, além de estames usualmente menores que o cálice.

14. Sapium obovatum Klotzsch ex Müll. Arg., Linnaea 32: 120. 1863. Figs. 6h-o; 9d-f

Arbustos 1,5-1,8 $\mathrm{m}$ alt.; ramos esverdeados, amarronzados ou cinéreos; estípulas 1,3-3 $\mathrm{mm}$ compr., triangulares a oval-triangulares, margem inteira; pecíolo 0,3-1,5 cm compr., glândulas cilíndricas a cônicas, laterais, opostas ou subopostas; lâmina 2,4-10,4 × 1,6-5,4 cm, predominantemente oboval, mas também oblongoelíptica a elíptica, base obtusa, ápices obtusos a arredondados, às vezes curtamente acuminados ou emarginados, margem dentada; nervuras secundárias arqueadas em relação à nervura principal, proeminente na face abaxial. Tirsos 3,1-5,5 cm compr., címulas 4 ou 5-floras; brácteas pistiladas 2,2-3 × 2,3-3,4 mm, largamente ovais, denticuladas, ápice obtuso; brácteas estaminadas 2-2,6 × 2,1-2,4 mm, obtruladas, ápice obtuso, glândulas de ambas as brácteas arredondadas; flores estaminadas $2,7-3,1 \mathrm{~mm}$, pedicelo $0,1-0,2$ mm compr., cálice com lobos com cerca de 1 $\mathrm{mm}$ compr. de margem inteira; flores pistiladas 1,2-1,9 mm compr., sésseis, cálice com lobos ovais de margem denticulada; ovário $0,7-1,7 \times 1-1,9$ $\mathrm{mm}$, globoso, estiletes unidos no terço inferior, curvados. Cápsula 0,8-1,1 × 0,7-1,3 enegrecida. Sementes $0,6-0,7 \times 0,5-0,9 \mathrm{~cm}$.

Material examinado: Alto Paraíso de Goiás, PNCV, próximo ao Salto de 120 metros, 14²'43"S, 47³1'25,1”W, 1.491 m, 2.XI.2013, P.H.B. Santos et al. 57 (UFG); imediações do Morro do Japonês a 500 metros da BR, 14'9'29,4'S, 47³4'3''W, 1.220 m, 12.X.2013, P.H.B. Santos et al. 82, 83, 84, 85, 86, 87 (UFG); 14'9'19,7'S, 47³7'4”W, 1.136 m, 22.XI.2013, P.H.B. Santos et al. 91 (UFG); região da Serra de Pouso Alto, 26.X.2012, R.C. Sodré et al. 248 (UFG); direita da GO239 , em direção ao povoado de São Jorge, cerca de 1,5 km do morro da Baleia, 14 $9,494^{\prime} \mathrm{S}, 4^{\circ} 37,915^{\prime} \mathrm{W}, 1.168$ m, 13.XII.2012, R.C. Sodré et al. 369, 370, 380 (UFG); limite nordeste do Parque, nas proximidades da GO-118, 13'55'37'S, 47²5'56”'W, 1.467 m, 14.XII.2012, R.C. Sodré et al. 385, 389 (UFG).

Ocorre no Brasil, Bolívia, Colômbia e Paraguai (Kruijt 2010), sendo no primeiro registrada no Amazonas, Bahia, Distrito Federal, Goiás, Mato Grosso, Mato Grosso do Sul, Minas Gerais e São Paulo (Kruijt 1996; BFG 2015). Foi coletada em cerrado ralo ou campo sujo próximo ao Morro do Japonês e também na região de Saltos.

Sapium obovatum se assemelha a $S$. glandulosum pelo formato das folhas não obovadas de alguns de seus indivíduos, glândulas peciolares inseridas lateralmente; mas diferencia-se pelas folhas de ápice obtuso a arredondado e margem plana ( $v s$. ápice cuculado inflexo e margem ligeiramente revoluta em $S$. glandulosum) e flores pistiladas com cálice dímero (vs. trímero).

15. Sebastiania brasiliensis Spreng., Neue Entdeck. Pflanzenk. 2: 118, 1821.

Figs. 6p-t; 9g,h

Arvoreta 2,5-3,5 m alt., látex leitoso, viscoso; ramos lenhosos, sem terminações espinescentes, cinéreos, esfoliantes, glabros. Folhas alternas, espiraladas, membranáceas, concolores ou discolores e neste caso com a face adaxial verde-escura e lustrosa e a abaxial verde opaca; pecíolo 0,3-0,5 cm compr.; lâmina $2-9,1 \times 1-3,6 \mathrm{~cm}$, elíptica ou oval-elíptica, base 

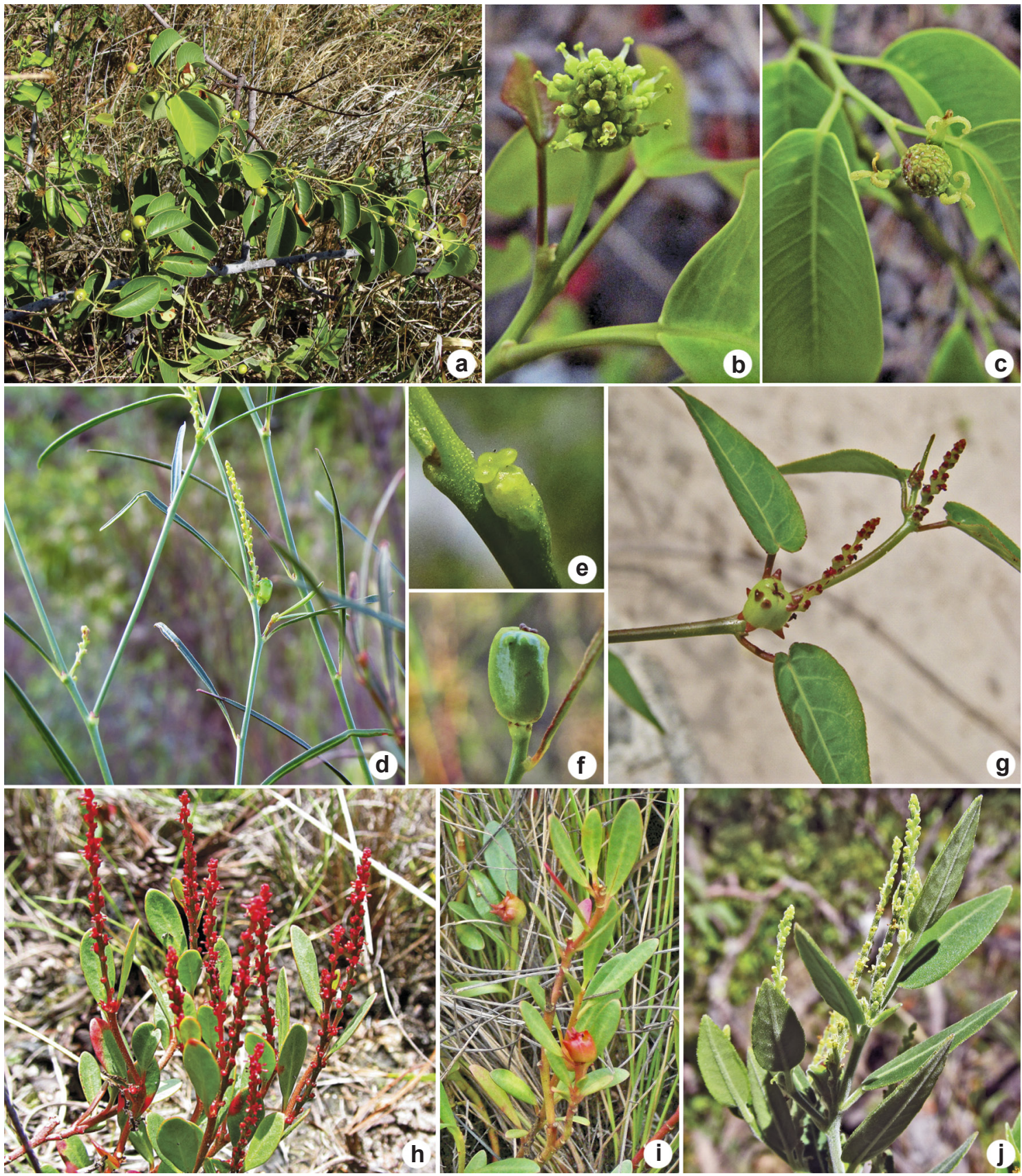

Figura 7 - a-c. Maprounea guianensis - a. hábito; b. tirso globoso mostrando as flores estaminadas; c. tirso globoso mostrando as flores pistiladas e os botões estaminados. d-f. Microstachys bidentata - d. ramos floridos; e. flor pistilada; f. cápsula. g. $M$. corniculata - ramo florido mostrando as inflorescências e cápsulas. h,i. $M$. crassifolia - h. hábito; i. ramo frutificado. j. M. daphnoides - ramo florido.

Figure 7 - a-c. Maprounea guianensis - a. habit; b. globose thyrses showing staminate flowers; c. globose thyrses showing pistillate flowers and staminate buds. d-f. Microstachys bidentata - d. flowering branches; e. pistillate flowers; f. capsules. g. $M$. corniculata - flowering branch showing inflorescences and capsule. h,i. M. crassifolia - h. habit; i. fruiting branch. j. M. daphnoides - flowering branch. 



Figura 8 - a-d. Microstachys ditassoides - a. hábito; b. tirso mostrando botões e flores estaminadas; c. base da inflorescência mostrando a flor pistilada com estiletes avermelhados; d. cápsula. e-f. M. serrulata - e. hábito; f. cápsula. g-i. Sapium glandulosum - g. ramo florido; h. tirso mostrando flores pistiladas; i. ramo frutificado.

Figure 8 - a-d. Microstachys ditassoides - a. habit; b. thyrse showing buds and flowers staminate; c. inflorescence base showing pistillate flower with reddish styles; d. capsule. e-f. M. serrulata - e. habit; f. capsules. g-i. Sapium glandulosum - g. flowering branch; h. thyrse showing pistillate flowers; i. fruiting branch. 

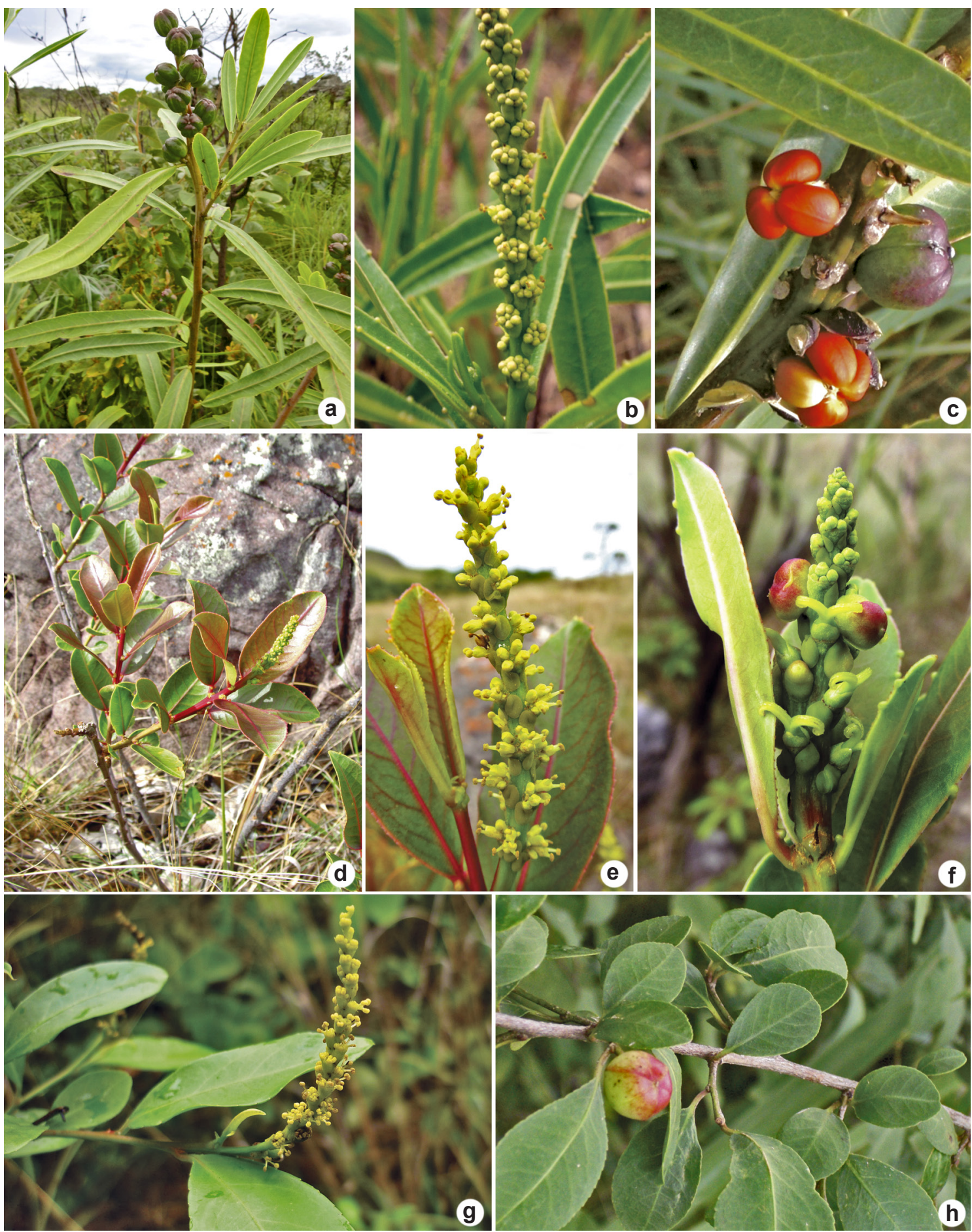

Figura 9 - a-c. Sapium haematospermum - a. ramo florido; b. tirso mostrando botões estaminados; c. cápsulas. d-f. Sapium obovatum - d. ramo florido; e. tirso mostrando flores estaminadas; $f$. tirso mostrando flores pistiladas e botões estaminados. g,h. Sebastiania brasiliensis - g. ramo florido; h. ramo com um fruto.

Figure 9 - a-c. Sapium haematospermum - a. flowering branch; b. thyrse showing staminate buds; c. capsules. d-f. Sapium obovatum - d. flowering branch; e. thyrse showing staminate flowers; f. thyrse showing pistillate flowers and staminate buds; g,h. Sebastiania brasiliensis - g. flowering branch; $\mathrm{h}$. branch with a fruit. 
obtusa a cuneada, margem esparsamente serreada com apículos glandulares, ápice agudo a curto acuminado, nervuras secundárias inclinadas em relação a principal, impressas. Tirsos $1-2,3 \mathrm{~cm}$ compr., unissexuais estaminados ou bissexuais com uma ou duas flores pistiladas basais e címulas estaminadas, 3-floras dispostas alternoespiraladamente na raque; Brácteas pistiladas 1,3-2,1 × 1,1-1,5 cm, ovais com ápice acuminado, margem serreada e um par de glândulas triangulares baselaterais adpressas; brácteas estaminadas 0,7-1 × 0,9-1,3 $\mathrm{mm}$, triangulares a largamente oval-triangulares, ápice obtuso, com um par de glândulas arredondadas a circulares, baselaterais e adpressas; flores estaminadas 1,8-2,3 mm, pedicelo ca. $0,3 \mathrm{~mm}$ compr., sépalas $0,7-1,1 \times 0,15-0,2 \mathrm{~mm}$, estreito-lanceoladas curvadas pelo ápice, estames 3, livres; flores pistiladas 2,2-2,8 mm compr., sésseis, sépalas 1,7-2,2 ×0,7-1,1 mm, triangulares, margem erosa, ápice acuminado, ovário 1,1-1,4 $\times$ 0,8-1,3 mm, glabro, sem córneos, estiletes unidos basalmente, curvos no ápice e achatados lateralmente. Cápsulas e sementes não observados. Material examinado: Cavalcante, sopé da Serra de acesso ao PNCV através da Fazenda Gavião, 14¹3'18,2"S, 47053'29,9"W, 1.491 m, 1.XI.2012, P.H.B. Santos et al. 79 (UFG); Fazenda Forquilha, antes de atravessar a cachoeira e da porteira que dá acesso aos criadouros de peixe, 1350'71,2"S, 47³4'90,1'W, 8.VI.2012, J.P. Santos et al. 463, 477 (UFG); sudoeste do PNCV acessado a partir da Fazenda Gavião, 14 13 '18'S, 4753'29,9'W, 577 m, 1.XI.2013, M.J. Silva. et al. 5524 (UFG).

Sebastiania brasiliensis, único táxon do gênero registrado aqui, se distribuí em todas as regiões do Brasil com exceção da Região Norte e atinge a Argentina, Bolívia, Paraguai e Uruguai (Pscheidt \& Cordeiro 2011). Neste estudo foi encontrado em bordas de pequenos rios em cerrado sensu stricto por volta de $800 \mathrm{~m}$ de altitude. Pode ser identificada pelos tirsos terminais com flores esparsas, látex branco e leitoso, gemas recobertas por um par de catafilos, brácteas de ambas as flores com um par de glândulas adpressas, flores estaminadas com três sépalas curvas no ápice, três estames livres e pistiladas com sépalas largamente ovais ou triangulares.

\section{Agradecimentos}

Agradecemos ao Conselho Nacional de Desenvolvimento Científico e Tecnológico (CNPq), o financiamento do projeto "Levantamento Florístico do Parque Nacional da Chapada dos Veadeiros, Goiás, Brasil", e as bolsas de Iniciação
Científica aos dois primeiros autores, e bolsa de Produtividade (Processo no. 307371/2013-1) ao terceiro autor; ao Sistema de Autorização e Informação em Biodiversidade / Instituto Brasileiro do Meio Ambiente e dos Recursos Naturais Renováveis (SISBIO / IBAMA), permitir a realização de trabalhos de campo; à equipe do Parque Nacional Chapada dos Veadeiros, fornecer alojamentos no interior do Parque; e a Cristiano Gualberto, as belas ilustrações.

\section{Referências}

BFG - The Brazil Flora Group (2015) Growing knowledge: an overview of seed plant diversity in Brazil. Rodriguésia 66: 1085-1113.

Brasil - Ministério de Minas e Energia (1982) Folha SD 23 Brasília: geologia, geomorfologia, pedologia, vegetação e uso potencial da terra / Projeto Radambrasil. O Projeto, Rio de Janeiro. 655p.

Esser H-J (1998) New combinations in Microstachys (Euphorbiaceae). Kew Bulletin 53: 955-960.

Esser H-J (1999) Taxonomic notes on Neotropical Maprounea (Euphorbiaceae). Novon 9: 32-35.

Esser H-J (2012) The tribe Hippomaneae (Euphorbiaceae) in Brazil. Rodriguésia 63: 209-225.

Esser H-J, Welzen PV \& Djarwaningsih T (1997) A phylogenetic classification of the Malesian Hippomaneae (Euphorbiaceae). Systematic Botany 22: 617-628.

Felfili JM (2007) A Chapada dos Veadeiros. In: Felfili, JM, Rezende AV \& Silva Júnior MC (2007) Biogeografia do bioma Cerrado. Ed. da Universidade de Brasília, Finatec, Brasília. Pp. 17-23.

Govaerts R, Frodin DG \& Radcliffe-Smith A (2000) Sebastiania. In: Govaerts R, Frodin DG, RadcliffeSmith A (eds.) World checklist and bibliography of Euphorbiaceae (and Pandaceae). Vol. 4. Royal Botanical Gardens, Kew. Pp. 1450-1464.

Kruijt RC (1996) A taxonomic monograph of Sapium Jacq., Anomostachys (Baill.) Hurus., Duvigneaudia J. Léonard and Sclerocroton Hochst. (Euphorbiaceae tribe Hippomaneae). Bibliotheca Botanica 146: 1-109.

McNeill J, Barrie FR, Buck WR, Demoulin V, Greuter W, Hawksworth DL, Herendeen PS, Knapp S, Marhold K, Prado J, Prud'homme van Reine WF, Smith GE, Wiersema JH \& Turland NJ (2012) International code of nomenclature for algae, fungi, and plants (Melbourne Code) adopted by the Eighteenth International Botanical Congress Melbourne, Australia, July 2011. Vol. 154. Regnum Vegetabile. A.R.G. Gantner Verlag, Ruggell. 240p.

Melo AL (2006) Revisão de Sebastiania Spreng. sensu stricto (Euphorbiaceae - Hippomaneae). Tese de Doutorado. Universidade Federal Rural de Pernambuco, Recife. $117 \mathrm{p}$. 
Mori SA, Silva LA, Lisboa G \& Coradin L (1989) Manual de manejo do herbário fanerogâmico. Centro de Pesquisas de Cacau, Ilhéus. 103p.

Müller J (1873) Euphorbiaceae. In: Martius CFP \& Eichler AG (eds.) Flora brasiliensis. Monachii, Lipsiae. Vol. 1, pars 2, pp. 1-752.

Oliveira LSD (2013) Sistemática do gênero Gymnanthes Sw. (Hippomaneae, Euphorbiaceae). Tese de Doutorado. Universidade Federal Rural de Pernambuco, Recife. 207p.

Pscheidt AC \& Cordeiro I (2012) Sinopse da tribo Hippomaneae Euphorbiaceae) no estado de São Paulo, Brasil. Hoehnea 39: 347-368.

Pscheidt AC (2015) O gênero Microstachys A. Juss. e a tribo Hippomaneae. Tese de Doutorado. Instituto de Botânica de São Paulo, São Paulo. 244p.

Ribeiro JF \& Walter BMT (1998) Fitofisionomias do bioma Cerrado. In: Sano SM \& Almeida SP (eds.) Cerrado: ambiente e flora. Embrapa Cerrados, Brasília. Pp. 87-166.

Santos VJ \& Sales MF (2009) A tribo Hippomaneae A. Juss. ex Spach. (Euphorbiaceae Juss.) no estado de Pernambuco, Brasil. Acta Botanica Brasílica 23: 976-990.
Silva MJ \& Esser H-J (2011) Two new taxa and two new combinations in Microstachys (Euphorbiaceae) from South America. Phytotaxa 32: 18-26.

Silva MJ, Pscheidt AC \& Cordeiro I (2016) Microstachys crassifolia sp. nov. (Euphorbiaceae) from Chapada dos Veadeiros, Goiás, Brazil. Nordic Journal of Botany 34: 364-369.

Thiers B [continuamente atualizado] Index herbariorum: a global directory of public herbaria and associated staff. New York Botanical Garden's Virtual Herbarium. Disponível em $<$ http://sweetgum.nybg. org/science/ih/>. Acesso em 10 janeiro 2017.

Veiga TC (2000) A importância do meio físico na Chapada dos Veadeiros e seu entorno. In: SEMARH/ GO. Secretaria de Meio Ambiente, Recursos Hídricos e Habitação - Área de Proteção Ambiental Pouso Alto, Goiânia. Pp. 1-26.

Webster GL (1994) Synopsis of the genera and suprageneric taxa of Euphorbiaceae. Annals of the Missouri Botanical Garden 81: 33-144.

Wurdack KJ \& Davis CC (2009) Malpighiales phylogenetics: Gaining ground on one of the most recalcitrant clades in the angiosperm tree of life. American Journal of Botany 96: 1551-1570. This is an open-access article distributed under the terms of the Creative Commons Attribution License. 